\title{
Fungal Endophytes: A Promising Frontier for Discovery of Novel Bioactive Compounds
}

\author{
Martin Muthee Gakuubi ${ }^{1,2}$, Madhaiyan Munusamy ${ }^{1}$, Zhao-Xun Liang ${ }^{2}$ and Siew Bee $\mathrm{Ng}^{1, *}$ \\ 1 Singapore Institute of Food and Biotechnology Innovation (SIFBI), Agency for Science, Technology and \\ Research (A*STAR), 31 Biopolis Way, \#01-02 Nanos, Singapore 138669, Singapore; \\ tp-gakuubimm@sifbi.a-star.edu.sg (M.M.G.); madhaiyanm@sifbi.a-star.edu.sg (M.M.) \\ 2 School of Biological Sciences, Nanyang Technological University, Singapore 637551, Singapore; \\ zxliang@ntu.edu.sg \\ * Correspondence: ngsb@sifbi.a-star.edu.sg
}

Citation: Gakuubi, M.M.;

Munusamy, M.; Liang, Z.-X.; Ng, S.B. Fungal Endophytes: A Promising Frontier for Discovery of Novel Bioactive Compounds. J. Fungi 2021, 7, 786. https://doi.org/10.3390/ jof7100786

Academic Editor: Gary A. Strobel

Received: 1 September 2021

Accepted: 16 September 2021

Published: 22 September 2021

Publisher's Note: MDPI stays neutral with regard to jurisdictional claims in published maps and institutional affiliations.

Copyright: (c) 2021 by the authors. Licensee MDPI, Basel, Switzerland. This article is an open access article distributed under the terms and conditions of the Creative Commons Attribution (CC BY) license (https:// creativecommons.org/licenses/by/ $4.0 /)$.

\begin{abstract}
For years, fungi have served as repositories of bioactive secondary metabolites that form the backbone of many existing drugs. With the global rise in infections associated with antimicrobial resistance, in addition to the growing burden of non-communicable disease, such as cancer, diabetes and cardiovascular ailments, the demand for new drugs that can provide an improved therapeutic outcome has become the utmost priority. The exploration of microbes from understudied and specialized niches is one of the promising ways of discovering promising lead molecules for drug discovery. In recent years, a special class of plant-associated fungi, namely, fungal endophytes, have emerged as an important source of bioactive compounds with unique chemistry and interesting biological activities. The present review focuses on endophytic fungi and their classification, rationale for selection and prioritization of host plants for fungal isolation and examples of strategies that have been adopted to induce the activation of cryptic biosynthetic gene clusters to enhance the biosynthetic potential of fungal endophytes.
\end{abstract}

Keywords: bioactive compounds; endophytic fungi; natural products; secondary metabolites

\section{Introduction}

Natural products, also known as secondary metabolites (SMs), are a diverse group of mainly low-molecular-weight and structurally diverse chemical entities that are produced by almost all living organisms, but mostly by microbes [1]. The use of natural products as a source of medicine dates back several millennia and is extensively described in the literature of ancient civilizations. There is evidence that the Chinese, Indians and Egyptians were using plants and plant extracts for treatment of human diseases thousands of years ago [2]. While plants have a long history as a source of beneficial SMs, microorganisms have equally played a key role in the evolution of drug discovery due to their impressive diversity, ease of growth and amenability to genetic manipulation.

In the early days of microbial-based drug discovery, the soil microbiota was the principal source of bioactive compounds [3,4]. However, with the increase in the rate of rediscovery of known compounds from soil microbes, there has been a need to widen the horizon in search of new sources of microbes with greater potential for discovery of novel therapeutic candidates. Among the most promising sources of microbes are those from underexplored and specialized niches, including plant-associated microbes, such as endophytes. Already, fascinating compounds with great therapeutic value such as anticancer agents, antibiotics, antiviral, antidiabetic and immunosuppressive compounds have been isolated from these largely untapped microbes [5-8]. 


\section{Fungal Endophytes}

Endophytes refers to a group of highly diverse microorganisms, often fungi and bacteria, that are found in association with plants. The term endophytes (endo = inside; phytón = plant) was coined by Anton de Bary in 1866 to denote fungi that live inside their host plant tissues-as opposed to 'epiphytes', a term assigned to fungi that are found on the surface of plants [9]. Endophytic fungi constitute a heterogeneous and diverse group of microbes that are found in essentially all types of plants growing in different climatic and ecological zones [10]. Fungal endophytes have been isolated from virtually all plant types including trees, shrubs, herbaceous plants, grasses, mosses and ferns and marine plants [11]. The number of endophytic fungi is estimated to be approximately one million based on the 6:1 ratio of fungal-plant species [12]. However, the actual figure may be much higher than this, given the fact that only a small fraction of the approximately $5 \%$ of fungal species have been described to date [13]. Furthermore, the validity of the 6:1 ratio has been questioned, with some authors suggesting that the ratio could be up to five times higher in areas such as tropical and subtropical regions [14].

Fungal endophytes were originally defined as fungal strains that colonize internal plant tissues without causing apparent harm or disease to their host [12,15]. However, this definition has evolved over the years and will undoubtedly undergo more redefinitions as more data continue to be generated from research in endophyte biology. First, it can be quite difficult at times to make a clear distinction between fungal endophytes, mycorrhizal and phytopathogenic fungi. For example, some fungal strains can be pathogenic to certain plants while having neutral or even beneficial qualities towards other host plants [16]. Some fungi have also been known to live as latent pathogens within their host plant tissues only for their pathogenicity to be activated once certain conditions become favorable [17]. Additionally, there is a grey area with regard to plant pathogens that have lost their virulence. Should they be considered as endophytes or pathogens? Moreover, the definition of fungal endophytes on the basis of pathogenicity rules out unculturable fungi whose phytopathogenicity may be difficult to ascertain [16].

Endophytic fungi consist primarily of members of Ascomycetes and occasionally Basidiomycetes and Zygomycetes [12]. The diversity of fungal endophytes varies greatly by location and is a function of the environment with all its variables, host plants' genotype and physiology, growth season, and anthropogenic influences, among other factors [18,19]. Even within the same geographical region, the diversity and abundance of endophytic fungi varies considerably among host plants, and even within different parts of the same host plants [20]. It has, for instance, been established that the diversity of fungal endophytes is much greater in the tropical and subtropical regions compared to other regions [18,21] Additionally, seasonal variations have also been cited as a major determinant of the distribution and diversity of fungal endophytes $[19,22]$.

\section{Classification of Fungal Endophytes}

Being a taxonomically diverse and polyphyletic group, endophytic fungi classification can be quite challenging. Numerous schemes have been adopted in classifying fungal endophytes on the basis of one or more aspects of their biology [23]. The earliest classification scheme for fungal endophytes is based on the phylogeny, ecological functions and life history strategies and categorized fungal endophytes into two main groups: the clavicipitaceous endophytes (C-endophytes) and nonclavicipitaceous endophytes (NC-endophytes) [23-25]. Clavicipitaceous endophytes, also referred to as the endophytes of grasses or class 1 endophytes, consist mainly of member belonging to the family Clavicipitaceae (Hypocreales; Ascomycota). This group consists of 27 known genera that include the free living and diverse collection of symbiotic species [24]. Nonclavicipitaceous endophytes on the other hand consist of a vastly diverse polyphyletic group whose members are not well defined taxonomically [25]. NC-endophytes are found in association with vascular and non-vascular plants, with the majority of its members belonging to the Dikarya subkingdom (Ascomycota or Basidiomycota). 
With the continued growth in the field of endophyte fungal biology, a number of other criteria for classifying endophytic fungi have emerged. These include classification on the basis of characteristics such as host range, mode of transmission and infection, reproduction strategies, host's sites of colonization, and the position of the fungi within the continuum of interactions with their hosts [23,24]. Fungal endophytes have, for instance, been classified on the basis of the host plant types and, thus, there are studies that have focused on fungal endophytes from specific plants, e.g., medicinal plants fungal endophytes [26], mangrove fungal endophytes [27], coniferous trees fungal endophytes [19] and fungal endophytes of grasses [28]. With regard to the modes of transmission, two main categories of fungal endophytes are recognized, namely, vertically and horizontally transmitted fungal endophytes. The former consists of fungal strains that are transmitted between host generations, mostly through seeds, while the latter consists of fungi that are transmitted between different individuals of a population through spores or other vegetative propagules [29].

Fungal endophytes have similarly been classified on the basis of their preferential colonization of specific host plant tissues. Studies have shown that most often, fungal endophytes exhibit preferential tissues colonization, whereby specific fungal strains are most likely to be localized in specific parts of the host plant rather than colonize the host systemically [23]. Thus, there are root endophytic fungi which are mostly isolated from host plants' roots [30] and foliar fungal endophytes which are found in hosts' stems and leaves [31]. Other common criteria for classifying fungal endophytes include their mode of reproduction, whereby fungal endophytes are classified as either sexual or asexual and with regard to the expression of infection, hence the differentiation between symptomatic and asymptomatic fungal endophytes [32].

\section{Isolation of Fungal Endophytes: Rationale for Plant Selection and Prioritization}

Practically, all of the higher plant species in natural ecosystems harbor one to several hundred species of endophytic fungi [20]. With such a high number of possible sources of fungal endophytes, ingenious strategies have to be adopted when prioritizing the selection of host plants for fungal isolation. This increases the likelihood of selecting host plants that might harbor uncharacterized fungi, thus, enhancing the prospect of discovering interesting molecules. Though no formalized guidelines exist on the selection of plant sources for the isolation of fungal endophytes, various authors have proposed some bioprospecting strategies that coupled with statistical and comparative analysis of the ever-increasing body of literature can be used to identify the most promising host plants.

A four-point set of criteria has been proposed that can be used as a rationale for selection of promising plant for the isolation of fungal endophytes [33]. It involves the selection of (i) plants from a distinctive ecological niche, unique biology and survival strategies; (ii) medicinal plants and plants of ethnobotanical importance; (iii) plants that are endemic to specific regions; and (iv) plants from biodiversity hotspots. The first consideration gives prominence to plants from unique biotopes and those with inimitable biology and survival strategies. The idea here is that such plants may have evolved some distinctive survival strategies, allowing them to host an equally rare collection of microbial endophytes. An example of such plants would be those that grow in the mangrove environment. Such plants have evolved unique morphological, ecological and physiological adaptations to extreme conditions of high salinity, fluctuating sea water levels, high temperature and constant water forces [34]. Indeed, mangrove plants have been found to host a collection of fungal endophytes that are capable of synthesizing a rich repertoire of bioactive secondary metabolites $[27,35]$.

Focusing on medicinal plants is another important proposition [20,36]. Of particular interest are plants with known ethnopharmacological usage among various local communities. The selection of such plants may be carried out directly through contact with the local communities, through ethnobotanical surveys studies or via a literature search. The aim is to assess whether the activity attributed to such plants may have anything to do with their 
associated fungal endophytes [37]. The focus on medicinal plants as a source of fungal endophytes in bioprospecting for bioactives has gained traction in recent years following the discovery of fungal strains that are capable of independently producing host-associated bioactive compounds $[38,39]$. Among the most well-known cases is that of an anticancer agent paclitaxel (trade name Taxol). Discovered originally from the bark of Taxus brevifolia, taxol remains one of the most potent anti-cancer agents. However, the quantity of the active ingredient in T. brevifolia is very low, making this source of the compound unsustainable [40]. A breakthrough came as a result of the discovery of paclitaxel-producing endophytic fungi Taxomyces andreanae from T. brevifolia, followed by the discovery of more paclitaxel-producing fungal endophytes from other Taxus and non-Taxus species [41,42]. Since then, other fungal endophytes have been characterized that are capable of producing similar bioactive molecules as their host plants (Table 1).

Table 1. Some fungal endophytes that have been reported to produce similar bioactive compounds as their host plants.

\begin{tabular}{|c|c|c|c|c|c|}
\hline Endophytic Fungi & Host Plant & $\begin{array}{l}\text { Bioactive } \\
\text { Compound }\end{array}$ & Structure & Bioactivity & Reference \\
\hline Altenaria alternata & Passiflora incarnata & Chrysin & & $\begin{array}{l}\text { Antibacterial, } \\
\text { anti-inflammatory, } \\
\text { anticancer effects }\end{array}$ & [43] \\
\hline $\begin{array}{l}\text { Alternaria alternata, } \\
\text { Phomopsis sp. and } \\
\text { Fomitopsis sp. }\end{array}$ & Miquelia dentata & Camptothecine & & Anticancer agent & [44] \\
\hline Aspergillus flavus & Solanum nigrum & Solamargine & & Anticancer activity & [45] \\
\hline $\begin{array}{c}\text { Aspergillus } \\
\text { nidulans, and } \\
\text { Aspergillus oryzae }\end{array}$ & Ginkgo biloba & Quercetin & & Anti-inflammatory & [46] \\
\hline $\begin{array}{c}\text { Chaetomium } \\
\text { globosum }\end{array}$ & $\begin{array}{l}\text { Hypericum } \\
\text { perforatum }\end{array}$ & Hypericin & & $\begin{array}{l}\text { Anti-inflammatory } \\
\text { effects, } \\
\text { antimicrobialand } \\
\text { antioxidant } \\
\text { activities }\end{array}$ & [47] \\
\hline $\begin{array}{c}\text { Chaetomium } \\
\text { globosum }\end{array}$ & $\begin{array}{l}\text { Hypericum } \\
\text { perforatum }\end{array}$ & Emodin & & $\begin{array}{l}\text { Anti-inflammatory } \\
\text { effects, } \\
\text { antimicrobialand } \\
\text { antioxidant } \\
\text { activities, }\end{array}$ & [47] \\
\hline $\begin{array}{l}\text { Chaetomium } \\
\text { globosum }\end{array}$ & Ginkgo biloba & Quercetin & & $\begin{array}{l}\text { Anti-inflammatory } \\
\text { and antiallergic } \\
\text { effects }\end{array}$ & [48] \\
\hline
\end{tabular}


Table 1. Cont.

\begin{tabular}{|c|c|c|c|c|c|}
\hline Endophytic Fungi & Host Plant & $\begin{array}{l}\text { Bioactive } \\
\text { Compound }\end{array}$ & Structure & Bioactivity & Reference \\
\hline $\begin{array}{l}\text { Colletotrichum } \\
\text { gloeosporioides }\end{array}$ & Forsythia suspensa & Phillyrin & & $\begin{array}{l}\text { Antioxidant, } \\
\text { anti-infl } \\
\text { ammatory, anti- } \\
\text { hyperlipidemia } \\
\text { and antipyretic } \\
\text { activities }\end{array}$ & [49] \\
\hline $\begin{array}{c}\text { Colletotrichum } \\
\text { gloeosporioides and } \\
\text { Periconia sp. }\end{array}$ & $\begin{array}{l}\text { Piper longum and } \\
\text { Piper nigrum }\end{array}$ & Piperine & & $\begin{array}{c}\text { Antibacterial, } \\
\text { antifungal, } \\
\text { anti-inflammatory } \\
\text { and } \\
\text { and antioxidant }\end{array}$ & {$[50,51]$} \\
\hline Epicoccum nigrum & $\begin{array}{l}\text { Hypericum } \\
\text { perforatum }\end{array}$ & Emodin & & $\begin{array}{l}\text { Antimicrobial, } \\
\text { anti-inflammatory } \\
\text { and antioxidant }\end{array}$ & [52] \\
\hline $\begin{array}{l}\text { Fusarium sp. and } \\
\text { Paecilomyces tenuis }\end{array}$ & Huperzia serrata & Huperzine A & & $\begin{array}{l}\text { Treatment of } \\
\text { Alzheimer's } \\
\text { disease }\end{array}$ & {$[53,54]$} \\
\hline Fusarium sp. & Mentha longifolia & Fusaripeptide A & & $\begin{array}{c}\text { Antifungal, } \\
\text { antimalarial and } \\
\text { cytotoxicity }\end{array}$ & [55] \\
\hline $\begin{array}{l}\text { Fusarium } \\
\text { oxysporum }\end{array}$ & Sabina recurva & Podophyllotoxin & & Anticancer agent & [56] \\
\hline $\begin{array}{l}\text { Fusarium } \\
\text { oxysporum }\end{array}$ & Catharanthus roseus & Vinblastine & & $\begin{array}{l}\text { Anticancer/antitumor } \\
\text { agent }\end{array}$ & [57] \\
\hline
\end{tabular}


Table 1. Cont

\begin{tabular}{|c|c|c|c|c|c|}
\hline Endophytic Fungi & Host Plant & $\begin{array}{l}\text { Bioactive } \\
\text { Compound }\end{array}$ & Structure & Bioactivity & Reference \\
\hline $\begin{array}{l}\text { Fusarium } \\
\text { oxysporum }\end{array}$ & Catharanthus roseus & Vincristine & & $\begin{array}{l}\text { Anticancer/antitumor } \\
\text { agent }\end{array}$ & [57] \\
\hline $\begin{array}{c}\text { Fusarium } \\
\text { proliferatum }\end{array}$ & Macleaya cordata & Sanguinarine & & $\begin{array}{l}\text { antibacterial, } \\
\text { antihelmintic, } \\
\text { antitumor }\end{array}$ & [58] \\
\hline Fusarium solani & $\begin{array}{c}\text { Camptotheca } \\
\text { acuminate and } \\
\text { Apodytes dimidiata }\end{array}$ & Camptothecine & & Antineoplastic & {$[44,59]$} \\
\hline $\begin{array}{l}\text { Fusarium solani, } \\
\text { Metarhizium } \\
\text { anisopliae and } \\
\text { Mucor rouxianus }\end{array}$ & Taxus chinensis & Paclitaxel & & $\begin{array}{l}\text { Anticancer/antitumor } \\
\text { agent }\end{array}$ & [60] \\
\hline Hypocrea lixii & Cajanus cajan & Cajanol & & $\begin{array}{l}\text { Antiplasmodial, } \\
\text { antimicrobial, } \\
\text { anticancer agent }\end{array}$ & [61] \\
\hline $\begin{array}{l}\text { Pestalotiopsis } \\
\text { pauciseta }\end{array}$ & $\begin{array}{l}\text { Cardiospermum } \\
\text { helicacabum }\end{array}$ & Paclitaxel & & $\begin{array}{l}\text { Anticancer/antitumor } \\
\text { agent }\end{array}$ & [62] \\
\hline $\begin{array}{l}\text { Pestalotiopsis } \\
\text { terminaliae }\end{array}$ & Terminalia arjuna & Paclitaxel & & $\begin{array}{c}\text { Anticancer/antitumor } \\
\text { agent }\end{array}$ & [60] \\
\hline
\end{tabular}


Table 1. Cont.

\begin{tabular}{|c|c|c|c|c|c|}
\hline Endophytic Fungi & Host Plant & $\begin{array}{l}\text { Bioactive } \\
\text { Compound }\end{array}$ & Structure & Bioactivity & Reference \\
\hline $\begin{array}{l}\text { Phialocephala } \\
\text { fortinii }\end{array}$ & $\begin{array}{l}\text { Podophyllum } \\
\text { peltatum }\end{array}$ & Podophyllotoxin & & $\begin{array}{c}\text { Anticancer, } \\
\text { antiviral, } \\
\text { antioxidant, } \\
\text { antibacterial and } \\
\text { anti-rheumatic } \\
\text { activities }\end{array}$ & [63] \\
\hline Phoma glomerata & Salvia miltiorrhiza & Salvianolic acid C & & $\begin{array}{l}\text { Cardiovascular/ } \\
\text { cerebrovascular }\end{array}$ & [64] \\
\hline $\begin{array}{l}\text { Phomopsis sp. and } \\
\text { Diaporthe sp. }\end{array}$ & Cinchona ledgeriana & Quinine & & $\begin{array}{l}\text { Antipyretic and } \\
\text { antimalarial }\end{array}$ & [65] \\
\hline $\begin{array}{l}\text { Phomopsis sp. and } \\
\text { Diaporthe sp. }\end{array}$ & Cinchona ledgeriana & Quinidine & & $\begin{array}{c}\text { Antipyretic and } \\
\text { antimalarial }\end{array}$ & [65] \\
\hline $\begin{array}{l}\text { Phomopsis sp. and } \\
\text { Diaporthe sp. }\end{array}$ & Cinchona ledgeriana & Cinchonidine & & $\begin{array}{c}\text { Antipyretic and } \\
\text { antimalarial }\end{array}$ & [65] \\
\hline $\begin{array}{l}\text { Phomopsis sp. and } \\
\text { Diaporthe sp. }\end{array}$ & Cinchona ledgeriana & Cinchonine & & $\begin{array}{c}\text { Antipyretic and } \\
\text { antimalarial }\end{array}$ & [65] \\
\hline Sordariomycetes sp. & Eucommia ulmoides & Chlorogenic acid & & $\begin{array}{l}\text { Antimicrobial and } \\
\text { antitumor }\end{array}$ & [66] \\
\hline $\begin{array}{l}\text { Trichoderma } \\
\text { atroviride }\end{array}$ & Salvia miltiorrhiza & Tanshinone I & & $\begin{array}{l}\text { Antibacterial and } \\
\text { anti-inflammatory }\end{array}$ & [67] \\
\hline $\begin{array}{l}\text { Trichoderma } \\
\text { atroviride }\end{array}$ & Salvia miltiorrhiza & Tanshinone IIA & & $\begin{array}{l}\text { Antibacterial and } \\
\text { anti-inflammatory }\end{array}$ & [67] \\
\hline $\begin{array}{c}\text { Thielavia } \\
\text { subthermophila }\end{array}$ & $\begin{array}{l}\text { Hypericum } \\
\text { perforatum }\end{array}$ & Emodin & & $\begin{array}{l}\text { Antimicrobial, } \\
\text { anti-inflammatory } \\
\text { and antioxidant }\end{array}$ & [59] \\
\hline
\end{tabular}


The isolation of fungi from endemic plants is another strategy that can enhance the prospect of discovering interesting fungal strains [33]. Having occupied a distinctive geographical area for a long time, many endemic plants may be host to a unique assortment of fungal endophytes with capacity for the biosynthesis of molecules with fascinating chemistry and activities [68]. The last approach is the prioritization of plants from biodiversity hotspots. Global biodiversity hotspots, such as tropical and subtropical regions, are host to the highest plant diversity [20]. Plants growing in such areas are subjected to a multitude of biotic and abiotic factors, competition for limited resources and high levels of selection pressure [69]. Over the years, such an environment is likely to have resulted in the emergence of unique and uncharacterized endophytic fungi.

\section{Bioactive Secondary Metabolites from Endophytic Fungi}

The capacity for biosynthesis of bioactives both beneficial (such as antibiotics, e.g., penicillin) and detrimental (such as mycotoxins, e.g., aflatoxin) by fungi has motivated a great deal of interest among natural product researchers. Endophytic fungi represent an inexhaustible source of important metabolites with a broad range of biological activities. The non-pathogenic nature of the majority of fungal endophytes makes most of the SMs derived from them more suited for human usage, as most are non-toxic to mammalian cells [70]. Some of the biologically active compounds that have been isolated from fungal endophytes include antibiotics, anticancer, antifungal, immunosuppressive and antiviral compounds (Figure 1). The extensive review articles have been published focusing on major classes of bioactive compounds sourced from fungal endophytes including antibiotics [71,72], antifungal compounds [73], antimycobacterial compounds [74], anticancer/cytotoxic compounds [25,75,76], antioxidants [77] and valuable enzymes [78,79].
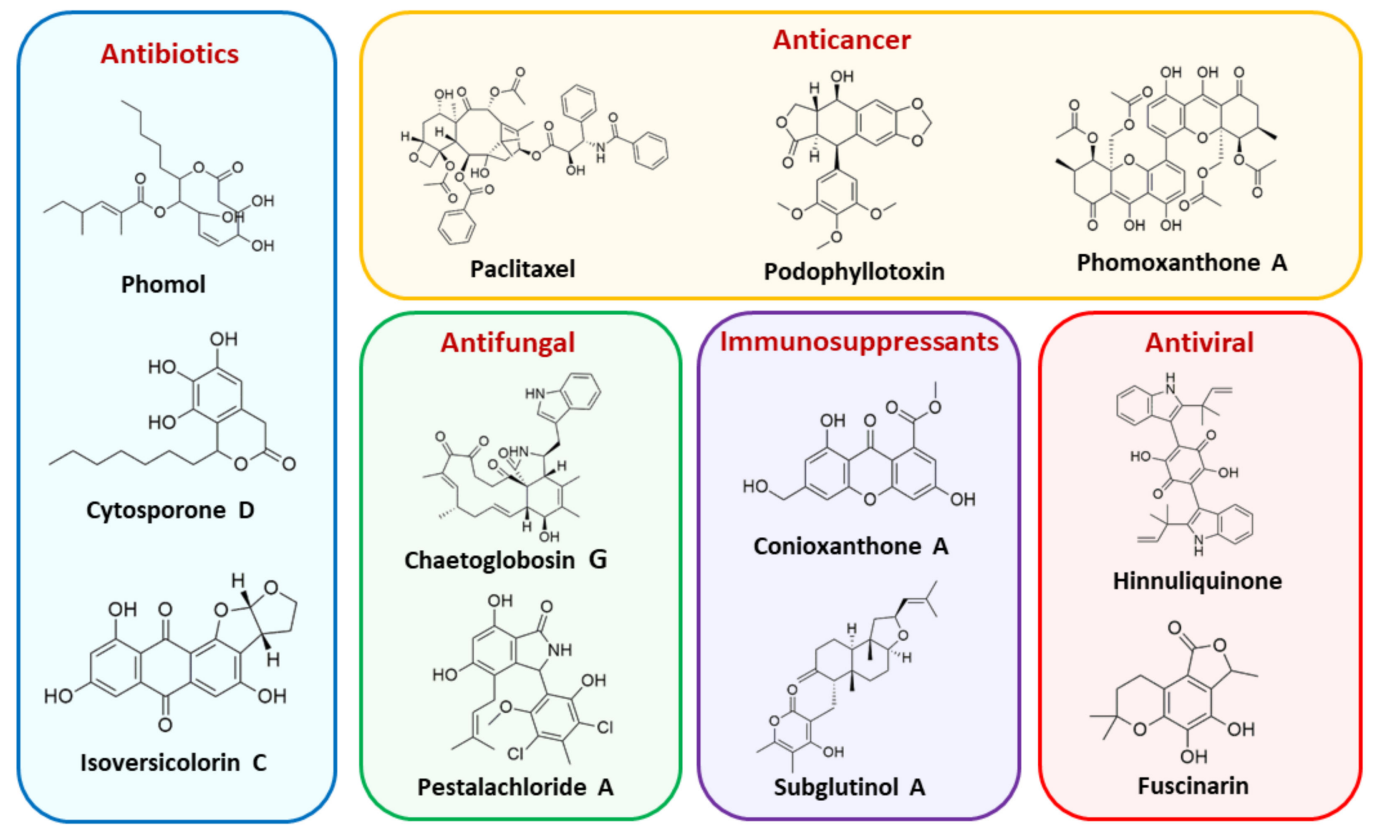

Figure 1. Some bioactive compounds isolated from fungal endophytes grouped according to their bioactivities.

\section{Enhancement of Secondary Metabolite Biosynthesis in Fungal Endophytes}

For a long time, the consensus was that fungal genes responsible for secondary metabolism are scattered throughout the organisms' genome in a similar manner to the genes involved in primary metabolism [80]. With the advancement in genomics, this notion of the architecture of fungal SMs biosynthetic pathways has since been dispelled, and two main principles have since been established: (i) genes that encode the enzymes needed for the biosynthesis and transport of SMs as well as pathway-specific regulatory genes are clustered on a single gene locus, forming biosynthetic gene clusters (BGCs) [81,82]. 
This design of fungal SMs biosynthetic genes has enabled the development of computer algorithms that can predict the core enzymes involved in the biosynthesis of various classes of SMs [83]. (ii) The number of biosynthetic gene clusters outnumbers that of SMs detected for any fungal strain by far $[80,84]$. The inconsistency between the actual number of BGCs and the number of characterized chemical entities produced by any given fungi is attributed to the fact that most BGCs remain silent or are only weakly expressed under standard laboratory growth conditions $[85,86]$. Arising from this observation, therefore, is the need to come up with techniques that can be used to induce the activation of cryptic biosynthetic pathways to enhance SMs biosynthesis in fungal endophytes. Below, we highlight some of the approaches that have been employed to activate silent gene cluster in fungal endophytes (Figure 2).

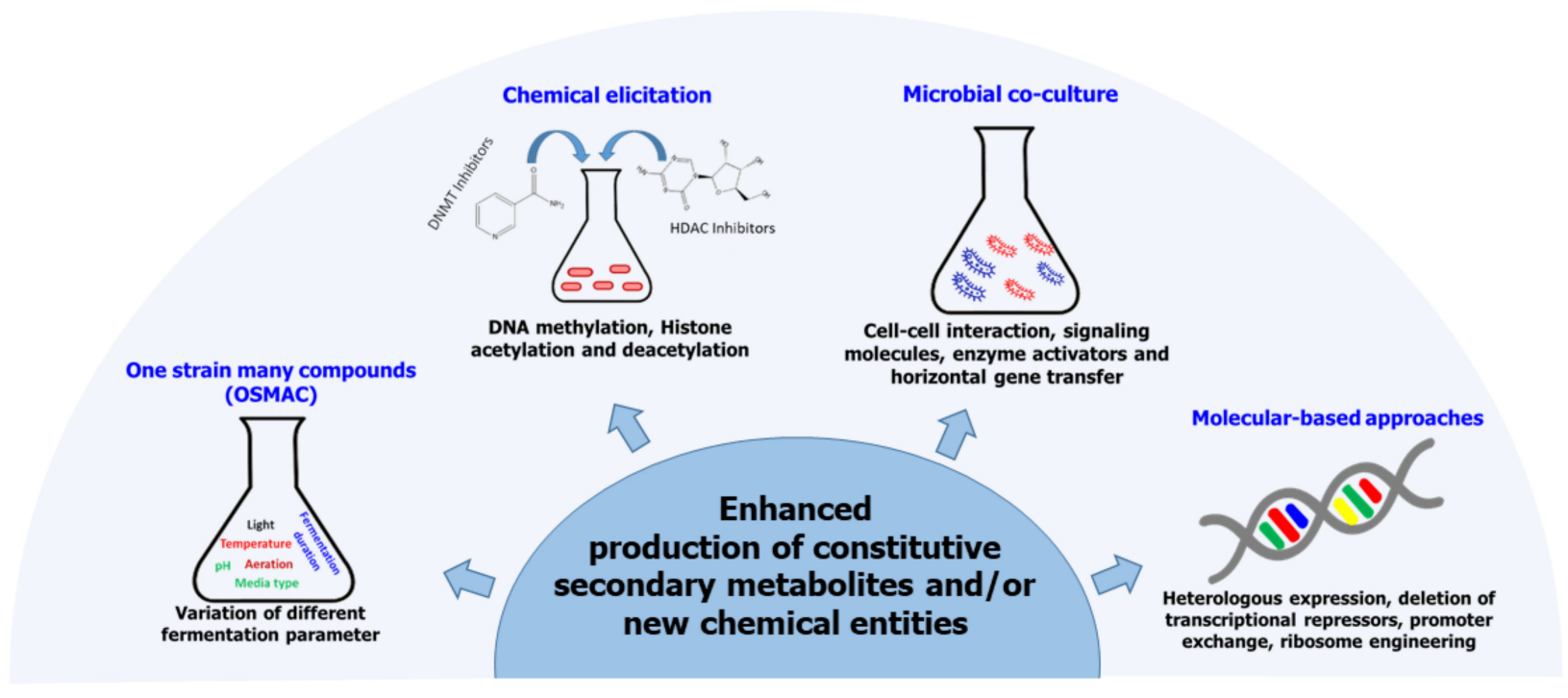

Figure 2. Some approaches that have been employed to enhance secondary metabolites biosynthesis in fungal endophytes.

\subsection{One-Strain Many-Compound (OSMAC) Approach}

The one-strain many-compound (OSMAC) concept was coined following an observation that changes in various cultivation parameters are capable of altering the SM biosynthetic profiles of microbes, leading to the discovery of new compounds [87]. Through systematic manipulation of media composition, aeration, culture vessel and use of selected enzyme inhibitors, up to 20 different SMs were isolated from a single microbe [87]. Similar results have been obtained in other studies through manipulation of the abovementioned among other culture growth conditions. Such changes have been found to induce changes not only in the amount of a specific metabolites, but have, in many instances, resulted in the biosynthesis of novel chemical entities altogether [88,89].

While manipulation of media composition has traditionally been used as a tool to optimize the production of already known metabolites, this technique has recently found widespread application as a mean of awakening cryptic or poorly expressed BGCs in fungal endophytes. In one such study, growth of Pestalotiopsis photiniae, an endophytic fungus isolated from Roystonea regia in SA media resulted in the isolation of Photinides A-F [90]. The growth of the same strain in solid rice media under static conditions resulted in the production of two new $\delta$-lactone derivatives: photipyrones $A$ and $B$ together with four known analogues of the two compounds that were not produced by the strain grown in SA media [91]. In another study, Bulgaria inquinans, an endophytic fungus isolated from Viscum album, was fermented in solid Czapek medium and later in the same media supplemented with a mixture of $\mathrm{MgSO}_{4}, \mathrm{NaNO}_{3}$ and $\mathrm{NaCl}$ salts [92]. Numerous compounds were identified from the cultures grown in salt-supplemented Czapek media that were not detectable in cultures grown in normal Czapek media. Among the isolated new 
compound was bulgarilines $\mathrm{B}$, which showed strong cytotoxic activity against the murine lymphoma cell line, L5178Y. In another OSMAC-driven study, production of metabolites by endophytic fungi Dothideomycetes sp. CRI7 isolated from the roots of Tiliacora triandra, were found to vary considerably not only on the basis of the culture media but also the source of the malt and potato ingredients in Czapek malt agar and PDB media, respectively [93]. When fermented in PDB medium prepared from fresh potato tubers, Dothideomycetes sp. CRI7 produced a tricyclic polyketide and three azaphilone derivatives. The same strain when grown in PDB media prepared from commercial potato powder produced three hitherto-unknown compounds that were absent from cultures grown in PDB prepared from fresh potato tubers. Furthermore, the growth of the fungal strain in Czapek malt media prepared from commercial malt extracts sourced from different countries completely altered Dothideomycetes sp. CRI7's metabolite profile. Some of the isolated compound exhibited cytotoxic activity against three cancer cell lines, while one had the radical scavenging and aromatase inhibitory activity [93]. The OSMAC growth strategy was found to alter the SM biosynthetic profile of Clonostachys rosea B5-2, an endophytic fungus isolated from mangrove plants. The addition of apple juice into the solid rice medium induced the production of a known compound, (-)-vertinolide in addition to four novel compounds, namely, (-)-dihydrovertinolide and clonostach acids A, B and C. (-)-dihydrovertinolide exhibited moderate phytotoxic activity against lettuce seedlings [94].

Even the type of water used for media preparation can result in a remarkable change in the biosynthetic profile of fungal endophytes. Endophytic fungus Paraphaeosphaeria quadriseptata produced different types and quantities of secondary metabolites when grown in PDB medium prepared with tap and when the same media was prepared using distilled water [95]. These changes were attributed to the presence of certain traces ions such as $\mathrm{Cu}^{2+}, \mathrm{Cd}^{2+}$ and $\mathrm{Cr}^{3+}$ in tap water. Another factor that has been shown to influence metabolite production among fungal endophytes is the volume of the growth culture. In one study, fermentation of fungal strains in microtiter plates ( $1 \mathrm{~mL}$ of media per well) led to the biosynthesis of numerous antifungal metabolites that were not detected when the same strains were grown in 1-liter culture flasks [96]. Variations in the incubation temperature, type and intensity of light have likewise been found to induce or suppress the biosynthesis of specific SMs in fungal endophytes. For example, whereas the production of mycotoxin sterigmatocystin in Aspergillus sp. is repressed by white light [97], the same type of light is known to induce the biosynthesis of two mycotoxins, namely, alternariol and altertoxin in Alternaria alternata [98]. Other cultivation parameters that have been found to influence fungal SMs biosynthesis include the incubation time, media $\mathrm{pH}$, oxygen concentration and level of aeration and growth of fungal strains in either shake flasks or static cultures $[96,99,100]$.

Since its conceptualization, OSMAC has become a mainstream approach in microbial natural product research. Figure 3 shows that, within the first five years of the introduction of the term OSMAC (2002-2006), only two journal articles containing the phrase "one strain many compounds" or "OSMAC" within the title, abstract or as keywords were published, compared to 86 papers that have been published in the last five years (2016-2020).

\subsection{Microbial Co-Culture Approach}

In their natural habitats, microorganisms exist in complex multispecies communities consisting of members of their own and those of other populations. Such communities are characterized by intricate intra- and inter-species interactions that are in stark contrast with the mainly axenic laboratory cultivation systems [88,101]. These natural microbial communities consist of complex and dynamic interactions that can fall anywhere within the continuum of mutualism and antagonism, with most having arose as strategies for defense and/or competition for limited resources among other factors [102]. In a number of instances, it has been proven that the activation of cryptic BGCs among certain microbes require an ecological context such as closer interaction with other microbes, host plants for the plant-associated microorganisms and even animals [101,103,104]. Co-culture, also referred to as co-cultivation (for solid media) or mixed fermentation (for liquid media), 
is the growth of two or more microbial strains together with the aim of mimicking the myriad of interactions that occurs when microbes coexist naturally [102,105]. This social networking among microbes in nature is facilitated among other things by gene transfers and production of small diffusible signaling molecules that individual strains release into their surroundings [106]. Furthermore, by taking up specific resources and releasing various metabolites and chemicals, microorganisms modify their surroundings, which affect their growth and that of other resident microbes. Such close associations between microorganisms have been shown to lead to the alteration of the biosynthetic profile of the involved strains so often, sometimes resulting in the production of compounds that are not produced in monocultures $[1,96,101]$. This aspect has been exploited in natural product research through co-culture of selected microorganisms, either to enhance the biosynthesis of already identified metabolites that are produced in small quantities in axenic cultures or for induction of silent gene clusters resulting in the production of novel chemical entities altogether.

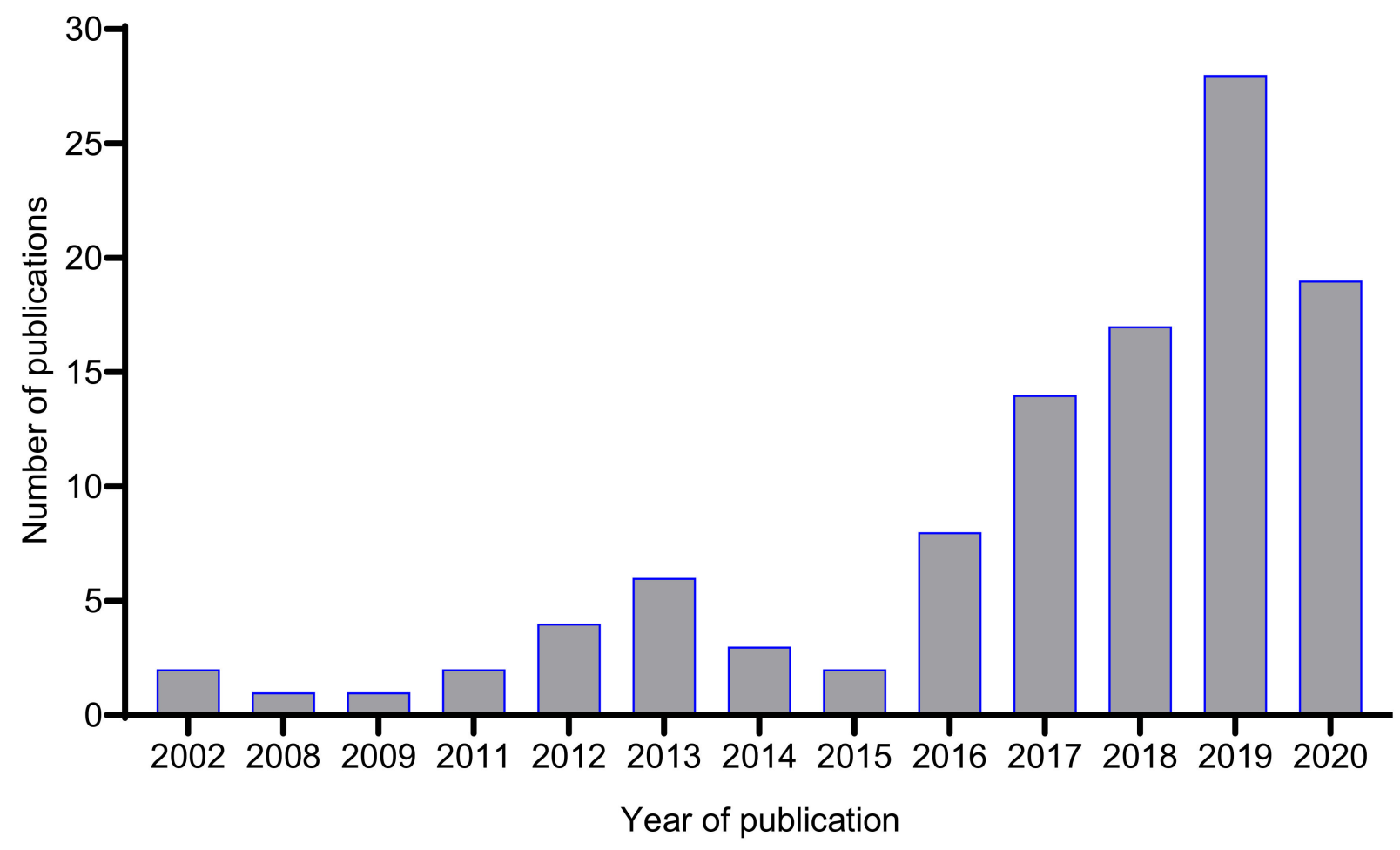

Figure 3. Number of journal articles published between 2002-2020 containing the phrase "one strain many compounds", "one strain-many compounds" or "OSMAC" within the title, abstract or as a keyword (data based on a search from the Web of Science, 14 January 2021).

Fungus-bacterium and fungus-fungus are the two main co-culture schemes that have been employed for the induction of cryptic BGCs in fungal endophytes. A coculture of endophytic fungus Fusarium tricinctum with a bacterium Bacillus subtilis led to a 78-fold increase in constitutive fungal secondary metabolites in addition to production of four compounds which were not detected in either of the monocultures, three of these compounds-macrocarpon C (1), 2-(carboxymethylamino) benzoic acid (2) and (-)-citreoisocoumarinol (3) of which were novel natural products [107] (Figure 4). Some of the isolated compounds, such as Enniatins B1, A1 and lateropyrone, exhibited good antibacterial activities with the first two inhibiting the growth of the inducing $B$. subtilis bacterial strain [107]. In another study, a co-culture of Chaetomium sp., an endophytic fungus isolated from Sapium ellipticum, with B. subtilis, resulted in an 8-fold upsurge in biosynthesis of different SMs. Seven compounds, five of which were novel, namely, shikimeran A (4), bipherin A (5), chorismeron (6), quinomeran (7) and serkydayn (8), were recovered from 
the co-cultures but not in axenic cultures [108]. In another fungal-bacterial co-culture experiment, Aspergillus austroafricanus, a fungal endophyte isolated from Eichhornia crassipes, was grown in the presence of either B. subtilis or Streptomyces lividans. While the fungal monoculture resulted in the production of two new xanthone dimers-austradixanthone and sesquiterpene (+)-austrosene, among other known compounds-a co-cultivation of the fungus with $B$. subtilis or S. lividans resulted in the biosynthesis of many diphenyl ethers, such as diorcinol (9), violaceol I (10) and violaceol II (11), in addition to a new austramide (12) [109]. Compound (9) exhibited antibacterial activity against a S. subtilis strain that had been used in the co-culture, while compounds (10) and (11) exhibited growth-inhibitory activities against Staphylococcus aureus [109]. A bacterium, Streptomyces rapamycinicus, when co-cultured with the fungus Aspergillus fumigatus, resulted in the activation of a silent PKS in the fungus, resulting in the production of a novel compound, fumicycline A (13) [110]. In another co-culture study involving the same two microorganisms, S. rapamycinicus activated a silent gene cluster in the fungus, resulting in induced biosynthesis of a novel metabolite, fumigermin (14), by the fungus [101]. Interestingly, the new compound, which is structurally similar to bacterial germicidins, was found to reversibly inhibit the germination of the spores in the inducing bacteria [101]. Furthermore, in both studies, the induced biosynthesis of the new metabolites required an intimate physical contact between the co-cultured microorganisms, ruling out the involvement of diffusible signaling molecules from the inducing bacteria [101,110].

Fungal-fungal co-cultures have, likewise, been used to enhance SM production in fungal endophytes. Paraconiothyrium sp., a paclitaxel-producing endophytic fungus, when co-cultured with Alternaria sp., another endophytic fungus, led to a 3-fold increase in the production of paclitaxel [111]. Furthermore, when Phomopsis sp., another endophytic fungus was included in the co-culture, there was an up to 7.8 -fold upsurge in the production of paclitaxel recorded in comparison to the amount obtained when Paraconiothyrium sp. was grown axenically [111]. A co-culture of two endophytic fungi-Epicoccum sorghinum FT1062 and Camporesia sambuci FT1061, isolated from Rhodomyrtus tomentosa-induced the production of a novel $\mathrm{N}$-methoxypyridone analog (15)] in addition to four other known compounds that were absent in the two monocultures [112]. In another study, a co-culture of two endophytic fungi Fusarium tricinctum and Fusarium begonia led to the biosynthesis of two novel depsipeptides, namely, subenniatin A (16) and subenniatin B (17), none of which were detected in axenic cultures [113]. The two compounds, however, showed no antibacterial or cytotoxic activity against a panel of bacterial pathogens and cancer cell lines, respectively [113]. A mixed fermentation of Phoma sp., a fungal endophyte and Armillaria sp., fungal symbiont resulted in the biosynthesis of five new compounds, including two phenolic compounds, namely, phexandiol A (18) and B (19), and three aliphatic ester derivatives, designated phomester A (20), B (21) and C (22). None of these compounds, however, exhibited any significant antimicrobial or cytotoxic activity [114]. In another study, the growth of two marine-derived endophytic fungi isolated from South China Sea (strain numbers 1924 and 3893) together yielded a novel 1-isoquinolone, marinamide (23) and its methyl ester (24). Both compounds revealed comparable antibacterial activity and potent cytotoxic activity against selected cancer cell lines [115,116].

Co-cultivation is increasingly emerging as a powerful tool for unlocking the chemical diversity of fungal endophytes by enhancing the expression of cryptic or weakly expressed biosynthetic pathways. Co-culture has proven to be a particularly popular approach for enhancing the chemical diversity of microbial SMs, owing to its simplicity and low cost when compared with other more complex gene manipulation techniques. However, when working with many target strains, the method requires large screening of diverse strain combinations before coming up with the most promising combinations, a process that can be quite cumbersome. 
<smiles></smiles><smiles>COC(=O)c1cc(O)ccc1-c1ccc(O)cc1C(=O)OC</smiles><smiles>O=C(O)CNc1ccccc1C(=O)O</smiles>

2<smiles>C[C@H](O)C[C@@H](O)CC1Cc2cccc(O)c2C(=O)O1</smiles>

3<smiles>COC(=O)C1=CC(O)C(OC(C)=O)CC1</smiles>

4<smiles>C=C(Oc1cccc(C(=O)OC)c1)C(=O)O</smiles><smiles>COC(=O)C(O)CC(=O)c1ccc2ccccc2n1</smiles><smiles>COC(=O)c1cc(OC)c2oc(=O)c3cc(O)ccc3c2c1</smiles>

8<smiles>Cc1cc(O)cc(Oc2cc(C)cc(O)c2)c1</smiles>

9<smiles>Cc1cc(O)c(O)c(Oc2cc(C)cc(O)c2O)c1</smiles>

10<smiles>Cc1cc(O)c(Oc2cc(C)cc(O)c2O)c(O)c1</smiles>

11<smiles>Cc1cc(O)cc(Oc2cc(C)c(C(N)=O)c(O)c2)c1</smiles>

12<smiles>CC(=O)C=C1CC2(O)Cc3c(c(CC=C(C)C)c4cc(O)cc(O)c4c3O)C(=O)C2O1</smiles>

13<smiles>C/C=C(\C)c1oc(=O)c(C)c(O)c1C</smiles>

14<smiles>CC[C@H]1Oc2ccn(OC)c(=O)c2[C@@H]2[C@@H](C)C[C@@H](C)[C@H](O)[C@@]21O</smiles>

15<smiles>CC(C)[C@H](O)C(=O)N(C)[C@H](C(=O)O[C@H](C(=O)N(C)[C@H](C(=O)O)C(C)C)C(C)C)C(C)C</smiles>

16<smiles>CC[C@H](C)[C@H](C(=O)OC(C(=O)N(C)C(C(=O)O)C(C)C)C(C)C)N(C)C(=O)[C@@H](O)C(C)C</smiles>

17<smiles>CCC[C@H](O)C/C=C/[C@H](O)CCCC(=O)OC</smiles>

20<smiles>CCC[C@H](O)C/C=C/[C@H](O)CCCC(=O)OCCCCCNC(C)=O</smiles>

22<smiles>CCCC[C@H](O)[C@@H](O)c1ccccc1O</smiles>

18<smiles>CCCC[C@H](O)[C@H](O)c1ccccc1O</smiles>

19<smiles>CCC[C@H](O)C/C=C/[C@H](O)CCCC(=O)OCC(O)CO</smiles>

21<smiles>O=C(O)c1c(-c2ccc[nH]2)[nH]c2ccccc2c1=O</smiles>

23<smiles>COC(=O)c1c(-c2ccc[nH]2)[nH]c2ccccc2c1=O</smiles>

24

Figure 4. Some of the new compounds that have been isolated as a result of co-cultures of endophytic fungi with bacteria or with other fungal strains.

\subsection{Chemical Epigenetic Modification}

Like all other living organisms, fungi are ingrained with an intricate network of multi-level regulatory systems that govern gene expression. These control mechanisms, though essential for normal growth and development, place some restrictions on secondary 
metabolism. The regulation of fungal secondary metabolism is a complex process that is dependent upon an intricate network of cellular, chemical and genetic determinants [117]. It occurs via the cluster-specific regulators, as well as globally acting regulators. The latter are usually encoded by genes that are not associated with any specific gene cluster and are mediated by a wide range of signals or triggers $[118,119]$. Chromatin-level control of gene silencing or activation has been identified as one of the mechanisms involved in the regulation of fungal SMs biosynthesis [83,118]. One approach that has been shown to allow fungi to circumvent such regulatory roadblocks is through the use of small chemical molecules known as epigenetic modifiers [1,108]. Remodeling of the chromatin landscape by chemically targeting the histone and DNA post-translation modifications has been found to enhance the quantity of constitutive fungal secondary metabolites through the activation or suppression of SMs encoding gene clusters [120].

Chemical epigenetic modification is achieved through the cultivation of target strains in the presence of one or more of the chemical epigenetic modifier compounds, such as histone deacetylases (HDAC) inhibitors and DNA methyltransferases (DNMT) inhibitors. The addition of such compounds in growth cultures at micromolar or even nanomolar concentrations has been found to suppress or activate the associated enzymes, resulting in the reengineering of SMs biosynthetic pathways in fungi [121,122]. Figure 5 shows some of the chemical epigenetic modifiers that have been used in remodeling fungal secondary metabolism: 5-azacytidine (25), 5-aza-2'-deoxycytidine (decitabine) (26), and hydralazine hydrochloride (27), which are DNMT inhibitors. HDAC inhibitors, on the other hand, include suberoylanilide hydroxamic acid (vorinostat or SAHA) (28), Suberoyl bishydroxamic acid (SBHA) (29) trichostatin A (30), trapoxin B (31) sodium butyrate (32) valproic acid (33) and nicotinamide (34) [100,123].

Pestalotiopsis crassiuscula, an endophytic fungus isolated from Fragaria chiloensis, when grown in PDB in the presence of $500 \mu \mathrm{M} 5$-azacytidine, resulted in drastic chemical differences in the resultant extracts in comparison with those from the fungi grown in the absence of the DNMT inhibitor [121]. Three novel compounds, (35), (36) and (37), were produced as a result of chemical elicitation (Figure 6). However, none of the three compounds showed antifungal activity against selected fungal pathogens. In another study, two epigenetic modifiers, 5-azacytidine and sodium butyrate, were added separately and in combination at varied concentrations in cultures of Leucostoma persoonii, a mangrove-derived fungal endophyte [124]. Overall, HDAC-inhibited cultures enhanced the levels of three previously known compounds, cytosporone B (38), cytosporone C (39) and cytosporone E (40), and also resulted in the isolation of a previously uncharacterized cytosporone $\mathrm{R}(41)$. Cytosporone E displayed inhibitory activity against Plasmodium falciparum in addition to antibacterial activity and inhibition of biofilm formation in MRSA [124]. The growth of endophytic fungus Aspergillus fumigatus, isolated from Grewia asiatica in PDB containing $500 \mu \mathrm{M}$ of valproic acid, resulted in a decrease in the quantity of numerous compounds that were identified from the control culture. However, the concentration of fumiquinazoline $C(42)$ was found to increase ten-fold in cultures of strain grown in the presence of the HDAC inhibitor [122]. A study exploring the effect of epigenetic modification and co-cultivation of Chaetomium sp., an endophytic fungus with B. subtilis, revealed the production of isosulochrin (43) when the fungus was grown in solid rice media in the presence of either SAHA or 5-azacytidine. Furthermore, while compound (43) was detected in the co-culture of Chaetomium sp., with the bacterium, the two chemical elicitors were found to greatly enhance its accumulation [108]. The treatment of Eupenicillium sp., an endophytic fungus derived from Xanthium sibiricum with nicotinamide, an NAD+-dependent histone deacetylase inhibitor, resulted in the production of two novel compounds designated as eupenicinicol C (44) and D (45), as well as two known and biosynthetically related compounds, eujavanicol A (46) and eupenicinicol A (47). Compound (45) showed inhibitory activity against $S$. aureus and some noticeable cytotoxic activity against the human acute monocytic leukemia cell line (THP-1) [125]. 
Manipulation of the epigenetic environment using chemical elicitors has also been reported to induce the production of toxic SMs such as mycotoxins in fungal endophytes. Alternaria sp., an endophytic fungus isolated from Datura stramonium, when grown in the presence of $250 \mu \mathrm{M}$ of 5-azacytidine and/or $500 \mu \mathrm{M}$ of SAHA, produced five compounds that were not detected in the control culture [126]. These compounds included a mycotoxin alternariol (48) and two other derivatives, namely, alternariol-5-O-methyl ether (49) and 3'-hydroxy-5-methoxyalternariol (50), in addition to two other compounds, altenusin (51) and Compound (52), designated as (5S, 8S)-tenuazonic acid, an Alternaria toxin [126]. The growth of the fungus in the presence of the epigenetic modifiers additionally resulted in increased accumulation of a second Alternaria toxin, altertoxin II (53). In another study, growth of Dimorphosporicola tragani, an endophytic fungus isolated from Arthrocnemum macrostachyum, in the presence of 5-azacytidine and valproic acid, resulted in the induced biosynthesis of a numbers of compounds. Among these were three toxic compounds, dendrodolide E (54), G (55]) and I (56), that were not produced by the fungus grown in the absence of the two chemical elicitors [127].<smiles>Nc1ncn([C@@H]2O[C@H](CO)[C@@H](O)[C@H]2O)c(=O)n1</smiles>

25<smiles>O=C(CCCCCCC(=O)Nc1ccccc1)NO</smiles>

28<smiles>CC(/C=C/C(=O)NO)=C\[C@H](C)C(=O)c1ccc(N(C)C)cc1</smiles>

30<smiles>CCCC(=O)[OH+][NH3+]</smiles>

32<smiles>Nc1ncn([C@H]2C[C@H](O)[C@@H](CO)O2)c(=O)n1</smiles>

26<smiles>NNc1nncc2ccccc12</smiles>

27<smiles>O=C(CCCCCCC(=O)NO)NO</smiles><smiles>O=C(CCCCC[C@H](NC(=O)[C@H](Cc1ccccc1)NC(=O)C1CO1)C(=O)N1CCC[C@H]1Cc1ccccc1)C1CO1</smiles>

31<smiles>CCCC(CCC)C(=O)O</smiles>

33<smiles>NC(=O)c1cccnc1</smiles>

34

Figure 5. Some chemical epigenetic modifiers that have been used in fungal natural products research: DNA. methyltransferase inhibitors (25-27) and histone deacetylase inhibitors (28-34). 
<smiles>Cc1cc2oc(=O)c(C)c(O)c2cc1O</smiles>

35<smiles>CCCCCC1OC(=O)Cc2cc(O)cc(O)c21</smiles>

39

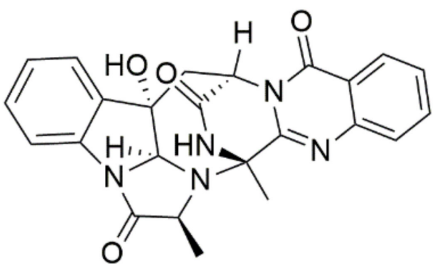

42<smiles>C/C=C(/C)c1cc(OC)cc(=O)o1</smiles>

36<smiles>CC(C)=CCc1ccc(O)c(C(=O)Oc2ccccc2CO)c1O</smiles>

37<smiles>CCCCCCCCCCCCCCCCCCC(=O)OCC</smiles>

38<smiles>CCCCCCCCCC(=O)c1c(O)cc(O)cc1CC(=O)OCC(O)CO</smiles>

41<smiles>CC[C@H](C)[C@H]1C=C[C@@H]2[C@@H](O)[C@@H](O)C[C@@H](C)[C@]2(C)[C@]1(C)C(=O)/C=C\NC(N)=O</smiles>

44

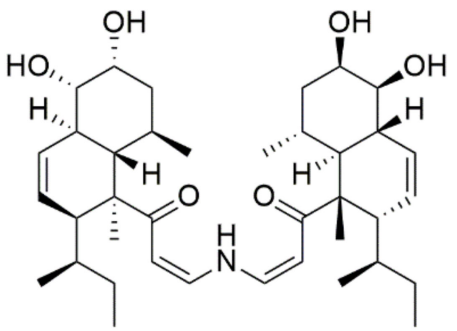

45<smiles>CC[C@H](C)[C@H]1C=C[C@H]2[C@@H](O)[C@@H](O)C[C@H](C)[C@]2(C)[C@]1(C)C(=O)CCO</smiles>

46<smiles>CC[C@H](C)[C@H]1C=C[C@H]2[C@@H](O)[C@H](O)C[C@H](C)[C@]2(C)[C@H]1C(=O)/C=C\O</smiles>

47<smiles>Cc1c(O)cc(C)c2c1oc(=O)c1c(O)cc(O)cc12</smiles>

48<smiles>COc1cc(O)c2c(=O)oc3c(C)c(O)cc(C)c3c2c1</smiles>

49<smiles>O=C1CCC2(O)c3c(ccc(O)c31)-c1ccc(O)c3c1C2C1OC1C3=O</smiles>

53<smiles>C[C@H]1C/C=C/C(=O)C/C=C/[C@H](O)CC(=O)O1</smiles>

54<smiles>COc1cc(O)c(C(=O)O)c(-c2cc(O)c(O)cc2C)c1</smiles>

51<smiles>C[C@H]1C/C=C/[C@H](O)C/C=C/[C@H](O)CC(=O)O1</smiles>

55<smiles>CCC(C)C1NC(=O)C(C(C)=O)=C1O</smiles>

52<smiles>C[C@@H]1CCC[C@H](O)C/C=C/[C@H](O)CC(=O)O1</smiles>

56

Figure 6. New compounds and those whose quantities have been reported to be enhanced by the growth of fungal endophytes in the presence of chemical epigenetic modifiers. 


\subsection{Molecular-Based Approaches}

The strategies for the activation of the silent BGCs described so far are, generally, untargeted in nature and, thus, do not explicitly permit an association between a newly identified secondary metabolite with any particular gene cluster. Instead, these approaches are meant to activate putative biosynthetic pathways whose identity or number may not be known beforehand. Genetic engineering of target strains is a more precise avenue that can be exploited to awaken cryptic BGCs, an approach that relies largely on genome mining. This approach is BGC specific and first involves the 'mining' of the whole genome of the target strains for the typical secondary metabolite gene clusters using appropriate bioinformatics tools $[128,129]$. Based on the architecture of the identified biosynthetic pathways, appropriate genetic manipulations of the strain of interest are carried out using any of the appropriate synthetic biology tools. Regulation of fungal SMs biosynthesis is a complex process that consists of interconnected pathways mediated by cluster-specific and global transcriptional complexes $[83,130]$. Pathway-specific regulatory genes which may be located within or outside a specific BGC are involved in the inactivation or repression of biosynthesis of SMs associated with a particular BGC [131]. Beside the pathway-specific regulators, the stimulation of global transcription factors is another possible approach. Global transcription factors which regulate genes that are not involved in secondary metabolism are coded for by genes outside the cluster region and regulate fungal response to various environmental signals such as nutrients, light, $\mathrm{pH}$ and stress [99,132].

Manipulation of pathway-specific regulators is an especially promising approach considering that up to $50 \%$ of fungal BCG have been found to harbor cluster-specific transcription factors [83]. The overexpression of such regulatory factors can result in the expression of cryptic pathways leading to the production of new metabolites. This approach was employed in Aspergillus nidulans through the overexpression of transcription factor gene apdR, resulting in the biosynthesis of two novel PKS-NRPS hybrid metabolites designated as aspyridone A and B that had not been previously isolated from this fungus [133]. Using the same approach, the activation of azaR in A. niger resulted in the production of six new azaphilone compounds designated as azanigerones A-F [134]. Similarly, the deletion of transcriptional repressors has also been used to enhance the biosynthesis of SMs or promote the production new fungal secondary metabolites. For example, deletion of xpp1, while resulting in the downregulation of primary metabolism, was found to enhance the upregulation of secondary metabolism, leading to significant increases in the quantity and diversity of SMs in Trichoderma reesei [135]. In another study, a double deletion of $P f C c l A$ and $P f c c l A$, two epigenetic-related genes in endophytic fungus Pestalotiopsis fici, led to the biosynthesis of fifteen novel polyketides, pestaloficiols T-W, 11 macrodiolide ficiolides A-K and ficipyrone $C$ [136]. In addition to the overexpression BCG-specific transcriptional factors and deletion of repressors, the exchange of native promoters with inducible or constitutive promoters is another strategy that has been employed to awaken cryptic BGC in fungi [137]. This approach was notably employed for the development of a system for heterologous expression of BGCs under the control of regulatable promoters and validated through the expression of numerous Aspergillus terreus BGCs in A. nidulans [138]. The identification and manipulation of negative regulators of SM clusters is another approach used to enhance the secondary metabolite biosynthesis in fungi. Multicluster regulator A $(M c r A)$ was uncovered as a gene involved in global downregulation of secondary metabolism in A. nidulans [139]. The deletion of McrA from A. nidulans and its homologs in a number of other fungal strains led to the upregulated production of several secondary metabolites, while its overexpression led to the suppression of SM biosynthesis [139]. The overexpression of global positive regulators has likewise been used to enhance SM production in fungi. For example, the overexpression of $L a e A$, a positive regulator found in Aspergillus spp., has been shown to enhance SM biosynthesis in members of this genus [140]. Other molecular-based strategies for the activation of silent BGCs in fungal endophytes have been extensively reviewed elsewhere and include 
those categorized as pleiotropic approaches, such as manipulation of global regulators and ribosome [1], and heterologous host transfer [99,138].

It is worth mentioning that the choice of any of the approaches discussed herein will depend upon the requirements of individual researchers, the level of expertise and the nature of the fungal strains, among other factors. None of the approaches can be considered as superior, as each has its strengths and limitations.

\section{Conclusions and Future Prospects}

Endophytic fungi have emerged as promising resources with enormous potential in drug discovery. With only a small fraction of the more than 1 million estimated fungal endophytes investigated for their biosynthetic capacity, fungal endophytes remain a largely understudied resource for the discovery novel bioactive molecules. The discovery of endophytic fungal strains capable of producing plant-associated molecules raises the prospects of exploiting such strains as an alternative source of valuable compounds. For example, the discovery of paclitaxel-producing fungal endophytes paved the way for the production of paclitaxel through a semisynthetic process that involves 10 -deacetyl-baccatin III as a precursor, plant cell culture and the endophytic fungi. Such an approach for co-cultivation of fungal endophytes with plant cells may offer the possibilities for production of other useful bioactive compounds that are produced in unsustainable quantities in plants.

However, to derive the immense benefits and possibilities that fungal endophytes promise, a number of constraints need to be addressed. Among the limitations associated with bioprospecting for bioactives from fungal endophytes is the issue of unculturable fungal strains. While the diversification of isolation media has been shown to enhance the recovery rate of cultivable fungal endophytes, numerous studies have revealed that many endophytic fungal strains are never recovered from plant materials because they are unculturable. Although metagenomics techniques facilitate the detection of such strains, it remains a big challenge to assess such strains for their full SMs biosynthetic competencies using the available technologies. Moreover, even among the culturable strains, loss of viability or capacity for biosynthesis of the compounds of interest either as a result of longterm preservation and repeated sub-culturing is a common challenge. This has often led to the loss of promising fungal strains before they are well studied, and attempts at re-isolation of the same fungal strains from the original habitats are not always met with success. Lastly, the future of fungal endophytes as a source of bioactives is tied to that of their host plants. There is a positive correlation between plant diversity and endophytic fungal diversity. The increase in habitat loss and overexploitation of plants resources in different parts of the world are putting many plant species at a risk of extinction. The loss of such plants means a corresponding loss of an assortment of valuable fungal endophytes, many of which may be uncharacterized and potential producers of interesting chemical molecules.

Author Contributions: M.M.G. and S.B.N. conceptualized the project and prepared the manuscript with input from M.M. and Z.-X.L. All authors have read and agreed to the published version of the manuscript.

Funding: This research was funded by the Singapore Institute of Food and Biotechnology Innovation, Agency for Science, Technology and Research (A*STAR), Singapore.

Institutional Review Board Statement: Not applicable.

Informed Consent Statement: Not applicable.

Data Availability Statement: Not applicable.

Acknowledgments: The authors are grateful to the Singapore Institute of Food and Biotechnology Innovation, Agency for Science, Technology and Research (A*STAR), Singapore for the funding support.

Conflicts of Interest: The authors declare no conflict of interest. 


\section{References}

1. Baral, B.; Akhgari, A.; Metsä-Ketelä, M. Activation of microbial secondary metabolic pathways: Avenues and challenges. Synth. Syst. Biotechnol. 2018, 3, 163-178. [CrossRef] [PubMed]

2. Phillipson, J.D. Phytochemistry and medicinal plants. Phytochemistry 2001, 56, 237-243. [CrossRef]

3. Nesme, J.; Simonet, P. The soil resistome: A critical review on antibiotic resistance origins, ecology and dissemination potential in telluric bacteria. Environ. Microbiol. 2015, 17, 913-930. [CrossRef] [PubMed]

4. Donadio, S.; Monciardini, P.; Alduina, R.; Mazza, P.; Chiocchini, C.; Cavaletti, L.; Sosio, M.; Puglia, A.M. Microbial technologies for the discovery of novel bioactive metabolites. J. Biotechnol. 2002, 99, 187-198. [CrossRef]

5. Gouda, S.; Das, G.; Sen, S.K.; Shin, H.S.; Patra, J.K. Endophytes: A treasure house of bioactive compounds of medicinal importance. Front. Microbiol. 2016, 7. [CrossRef]

6. Debbab, A.; Aly, A.H.; Proksch, P. Bioactive secondary metabolites from endophytes and associated marine derived fungi. Fungal Divers. 2011, 49, 1-12. [CrossRef]

7. Rai, N.; Kumari Keshri, P.; Verma, A.; Kamble, S.C.; Mishra, P.; Barik, S.; Kumar Singh, S.; Gautam, V. Plant associated fungal endophytes as a source of natural bioactive compounds. Mycology 2021, in press. [CrossRef]

8. Preethi, K.; Manon Mani, V.; Lavanya, N. Endophytic fungi: A potential source of bioactive compounds for commercial and therapeutic applications. In Endophytes; Springer: Singapore, 2021; pp. 247-272.

9. Dutta, D.; Puzari, K.C.; Gogoi, R.; Dutta, P. Endophytes: Exploitation as a tool in plant protection. Braz. Arch. Biol. Technol. 2014, 57, 621-629. [CrossRef]

10. Chowdhary, K.; Kaushik, N.; Raimundo, M. Endophytic fungi and their metabolites isolated from Indian medicinal plant. Phytochem. Rev. 2012, 467-485. [CrossRef]

11. Abhijeet Singh, Y.M. Understanding the biodiversity and biological applications of endophytic fungi: A Review. J. Microb. Biochem. Technol. 2014, S8, 1-11. [CrossRef]

12. Sun, X.; Guo, L.D. Endophytic fungal diversity: Review of traditional and molecular techniques. Mycology 2012, 3, 65-76. [CrossRef]

13. Chávez, R.; Fierro, F.; García-Rico, R.O.; Vaca, I. Filamentous fungi from extreme environments as a promising source of novel bioactive secondary metabolites. Front. Microbiol. 2015, 6, 903. [CrossRef]

14. Gamboa, M.A.; Laureano, S.; Bayman, P. Measuring diversity of endophytic fungi in leaf fragments: Does size matter? Mycopathologia 2003, 156, 41-45. [CrossRef] [PubMed]

15. Petrini, O.; Sieber, T.N.; Toti, L.; Viret, O. Ecology, metabolite production, and substrate utilization in endophytic fungi. Nat. Toxins 1993, 1, 185-196. [CrossRef] [PubMed]

16. Hardoim, P.R.; van Overbeek, L.S.; Berg, G.; Pirttilä, A.M.; Compant, S.; Campisano, A.; Döring, M.; Sessitsch, A. The hidden world within plants: Ecological and evolutionary considerations for defining functioning of microbial endophytes. Microbiol. Mol. Biol. Rev. 2015, 79, 293-320. [CrossRef]

17. Kloepper, J.W.; McInroy, J.A.; Liu, K.; Hu, C.H. Symptoms of fern distortion syndrome resulting from inoculation with opportunistic endophytic fluorescent Pseudomonas spp. PLoS ONE 2013, 8, e58531. [CrossRef]

18. Arnold, A.E.; Maynard, Z.; Gilbert, G.S.; Coley, P.D.; Kursar, T.A. Are tropical fungal endophytes hyperdiverse? Ecol. Lett. 2000, 3, 267-274. [CrossRef]

19. Kim, C.K.; Eo, J.K.; Eom, A.H. Diversity and seasonal variation of endophytic fungi isolated from three conifers in Mt. Taehwa, Korea. Mycobiology 2013, 41, 82-85. [CrossRef]

20. Meshram, V.; Gupta, M. Endophytic Fungi: A Quintessential Source of Potential Bioactive Compounds; Cambridge University Press: Cambridge, UK, 2019; ISBN 9781108607667.

21. Banerjee, D. Endophytic fungal diversity in tropical and subtropical plants. Res. J. Microbiol. 2011, 6, 54-62. [CrossRef]

22. Materatski, P.; Varanda, C.; Carvalho, T.; Dias, A.B.; Campos, M.D.; Rei, F.; Félix, M.d.R. Spatial and temporal variation of fungal endophytic richness and diversity associated to the phyllosphere of olive cultivars. Fungal Biol. 2019, 123, 66-76. [CrossRef]

23. Bamisile, B.S.; Dash, C.K.; Akutse, K.S.; Keppanan, R.; Wang, L. Fungal endophytes: Beyond herbivore management. Front. Microbiol. 2018, 9, 1-11. [CrossRef] [PubMed]

24. Rodriguez, R.J.; White, J.F.; Arnold, A.E.; Redman, R.S. Fungal endophytes: Diversity and functional roles: Tansley review. New Phytol. 2009, 182, 314-330. [CrossRef] [PubMed]

25. Uzma, F.; Mohan, C.D.; Hashem, A.; Konappa, N.M.; Rangappa, S.; Kamath, P.V.; Singh, B.P.; Mudili, V.; Gupta, V.K.; Siddaiah, C.N.; et al. Endophytic fungi-alternative sources of cytotoxic compounds: A review. Front. Pharmacol. 2018, 9, 1-37. [CrossRef]

26. Kaul, S.; Gupta, S.; Ahmed, M.; Dhar, M.K. Endophytic fungi from medicinal plants: A treasure hunt for bioactive metabolites. Phytochem. Rev. 2012, 11, 487-505. [CrossRef]

27. Demers, D.; Knestrick, M.; Fleeman, R.; Tawfik, R.; Azhari, A.; Souza, A.; Vesely, B.; Netherton, M.; Gupta, R.; Colon, B.; et al. Exploitation of mangrove endophytic fungi for infectious disease drug discovery. Mar. Drugs 2018, 16, 376. [CrossRef] [PubMed]

28. Tanaka, A.; Takemoto, D.; Chujo, T.; Scott, B. Fungal endophytes of grasses. Curr. Opin. Plant Biol. 2012, 15, 462-468. [CrossRef] [PubMed]

29. Daley, D.K.; Brown, K.J.; Badal, S. Fungal Metabolites. In Pharmacognosy: Fundamentals, Applications and Strategy; Elsevier Inc.: Amsterdam, The Netherlands, 2017; pp. 413-421, ISBN 9780128020999.

30. Chadha, N.; Mishra, M.; Prasad, R.; Varma, A. Root endophytic fungi: Research update. J. Biol. Life Sci. 2014, 5, 135. [CrossRef] 
31. Jia, Q.; Qu, J.; Mu, H.; Sun, H.; Wu, C. Foliar endophytic fungi: Diversity in species and functions in forest ecosystems. Symbiosis 2020, 80, 103-132. [CrossRef]

32. Terhonen, E.; Blumenstein, K.; Kovalchuk, A.; Asiegbu, F.O. Forest tree microbiomes and associated fungal endophytes: Functional roles and impact on forest health. Forests 2019, 10, 42. [CrossRef]

33. Strobel, G.; Daisy, B. Bioprospecting for microbial endophytes and their natural products. Microbiol. Mol. Biol. Rev. 2003, 67, 491-502. [CrossRef]

34. Shearer, C.A.; Descals, E.; Kohlmeyer, B.; Kohlmeyer, J.; Marvanová, L.; Padgett, D.; Porter, D.; Raja, H.A.; Schmit, J.P.; Thorton, H.A.; et al. Fungal biodiversity in aquatic habitats. Biodivers. Conserv. 2007, 16, 49-67. [CrossRef]

35. Deshmukh, S.K.; Gupta, M.K.; Prakash, V.; Sudhakara Reddy, M. Mangrove-associated fungi: A novel source of potential anticancer compounds. J. Fungi 2018, 4, 101. [CrossRef] [PubMed]

36. Rana, K.L.; Kour, D.; Kaur, T.; Devi, R.; Negi, C.; Yadav, A.N.; Singh, K.; Saxena, A.K. Endophytic fungi from medicinal plants: Biodiversity and biotechnological applications. In Microbial Endophytes; Kumar, A., Radhakrishnan, E.K., Eds.; Woodhead Publishing: Cambridge, UK, 2020; pp. 273-305.

37. Tiwari, K. The future products: Endophytic fungal metabolites. J. Biodivers. Bioprospect. Dev. 2014, 2, 1-7. [CrossRef]

38. Zhao, J.; Zhou, L.; Wang, J.; Shan, T.; Zhong, L.; Liu, X.; Gao, X. Endophytic fungi for producing bioactive compounds originally from their host plants. Curr. Res. Technol. Educ. Trop. Appl. Microbiol. Microb. Biotechnol. 2010, 1, 567-576.

39. Venieraki, A.; Dimou, M.; Katinakis, P. Endophytic fungi residing in medicinal plants have the ability to produce the same or similar pharmacologically active secondary metabolites as their hosts. Hell. Plant Prot. J. 2017, 10, 51-66. [CrossRef]

40. Demain, A.L.; Vaishnav, P. Natural products for cancer chemotherapy. Microb. Biotechnol. 2011, 4, 687-699. [CrossRef]

41. Xiong, Z.Q.; Yang, Y.Y.; Zhao, N.; Wang, Y. Diversity of endophytic fungi and screening of fungal paclitaxel producer from Anglojap yew, Taxus $x$ media. BMC Microbiol. 2013, 13, 71. [CrossRef]

42. Roopa, G.; Madhusudhan, M.C.; Sunil, K.C.R.; Lisa, N.; Calvin, R.; Poornima, R.; Zeinab, N.; Kini, K.R.; Prakash, H.S.; Geetha, N. Identification of Taxol-producing endophytic fungi isolated from Salacia oblonga through genomic mining approach. J. Genet. Eng. Biotechnol. 2015, 13, 119-127. [CrossRef]

43. Seetharaman, P.; Gnanasekar, S.; Chandrasekaran, R.; Chandrakasan, G.; Kadarkarai, M.; Sivaperumal, S. Isolation and characterization of anticancer flavone chrysin (5,7-dihydroxy flavone)-producing endophytic fungi from Passiflora incarnata L. leaves. Ann. Microbiol. 2017, 67, 321-331. [CrossRef]

44. Shweta, S.; Zuehlke, S.; Ramesha, B.T.; Priti, V.; Mohana Kumar, P.; Ravikanth, G.; Spiteller, M.; Vasudeva, R.; Uma Shaanker, R. Endophytic fungal strains of Fusarium solani, from Apodytes dimidiata E. Mey. ex Arn (Icacinaceae) produce camptothecin, 10-hydroxycamptothecin and 9-methoxycamptothecin. Phytochemistry 2010, 71, 117-122. [CrossRef]

45. El-Hawary, S.S.; Mohammed, R.; Abouzid, S.F.; Bakeer, W.; Ebel, R.; Sayed, A.M.; Rateb, M.E. Solamargine production by a fungal endophyte of Solanum nigrum. J. Appl. Microbiol. 2016, 120, 900-911. [CrossRef] [PubMed]

46. Qiu, M.; Xie, R.S.; Shi, Y.; Zhang, H.; Chen, H.M. Isolation and identification of two flavonoid-producing endophytic fungi from Ginkgo biloba L. Ann. Microbiol. 2010, 60, 143-150. [CrossRef]

47. Kusari, S.; Lamshöft, M.; Zühlke, S.; Spiteller, M. An endophytic fungus from Hypericum perforatum that produces hypericin. J. Nat. Prod. 2008, 71, 159-162. [CrossRef] [PubMed]

48. Yuan, Z.; Tian, Y.; He, F.; Zhou, H. Endophytes from Ginkgo biloba and their secondary metabolites. Chin. Med. 2019, 14, 1-40. [CrossRef] [PubMed]

49. Zhang, Q.; Wei, X.; Wang, J. Phillyrin produced by Colletotrichum gloeosporioides, an endophytic fungus isolated from Forsythia suspensa. Fitoterapia 2012, 83, 1500-1505. [CrossRef] [PubMed]

50. Chithra, S.; Jasim, B.; Anisha, C.; Mathew, J.; Radhakrishnan, E.K. LC-MS/MS based identification of piperine production by endophytic Mycosphaerella sp. PF13 from Piper nigrum. Appl. Biochem. Biotechnol. 2014, 173, 30-35. [CrossRef] [PubMed]

51. Verma, V.C.; Lobkovsky, E.; Gange, A.C.; Singh, S.K.; Prakash, S. Piperine production by endophytic fungus Periconia sp. Isolated from Piper longum L. J. Antibiot. 2011, 64, 427-431. [CrossRef] [PubMed]

52. Vigneshwari, A.; Rakk, D.; Németh, A.; Kocsubé, S.; Kiss, N.; Csupor, D.; Papp, T.; Škrbić, B.; Vágvölgyi, C.; Szekeres, A. Host metabolite producing endophytic fungi isolated from Hypericum perforatum. PLoS ONE 2019, 14, e0217060. [CrossRef]

53. Su, J.Q.; Yang, M.H. Huperzine A Production by Paecilomyces tenuis YS-13, an endophytic fungus isolated from Huperzia serrata. Nat. Prod. Res. 2015, 29, 1035-1041. [CrossRef]

54. Le, T.T.M.; Hoang, A.T.H.; Nguyen, N.P.; Le, T.T.B.; Trinh, H.T.T.; Vo, T.T.B.; Quyen, D. Van A novel huperzine A-producing endophytic fungus Fusarium sp. Rsp5.2 isolated from Huperzia serrate. Biotechnol. Lett. 2020, 42, 987-995. [CrossRef]

55. Ibrahim, S.R.M.; Abdallah, H.M.; Elkhayat, E.S.; Al Musayeib, N.M.; Asfour, H.Z.; Zayed, M.F.; Mohamed, G.A. Fusaripeptide A: New antifungal and anti-malarial cyclodepsipeptide from the endophytic fungus Fusarium sp. J. Asian Nat. Prod. Res. 2018, 20, 75-85. [CrossRef] [PubMed]

56. Kour, A.; Shawl, A.S.; Rehman, S.; Sultan, P.; Qazi, P.H.; Suden, P.; Khajuria, R.K.; Verma, V. Isolation and identification of an endophytic strain of Fusarium oxysporum producing podophyllotoxin from Juniperus recurva. World J. Microbiol. Biotechnol. 2008, 24, 1115-1121. [CrossRef]

57. Kumar, A.; Patil, D.; Rajamohanan, P.R.; Ahmad, A. Isolation, purification and characterization of vinblastine and vincristine from endophytic fungus Fusarium oxysporum isolated from Catharanthus roseus. PLoS ONE 2013, 8, e71805. [CrossRef] 
58. Wang, X.J.; Min, C.L.; Ge, M.; Zuo, R.H. An endophytic sanguinarine-producing fungus from Macleaya cordata, Fusarium proliferatum BLH51. Curr. Microbiol. 2014, 68, 336-341. [CrossRef]

59. Kusari, S.; Zühlke, S.; Spiteller, M. An endophytic fungus from Camptotheca acuminata that produces camptothecin and analogues. J. Nat. Prod. 2009, 72, 2-7. [CrossRef] [PubMed]

60. Miao, Z.; Wang, Y.; Yu, X.; Guo, B.; Tang, K. A new endophytic taxane production fungus from Taxus chinensis. Appl. Biochem. Microbiol. 2009, 45, 81-86. [CrossRef]

61. Zhao, J.; Li, C.; Wang, W.; Zhao, C.; Luo, M.; Mu, F.; Fu, Y.; Zu, Y.; Yao, M. Hypocrea lixii, novel endophytic fungi producing anticancer agent cajanol, isolated from pigeon pea (Cajanus cajan [L.] Millsp.). J. Appl. Microbiol. 2013, 115, 102-113. [CrossRef]

62. Gangadevi, V.; Murugan, M.; Muthumary, J. Taxol determination from Pestalotiopsis pauciseta, a fungal endophyte of a medicinal plant. Shengwu Gongcheng Xuebao/Chin. J. Biotechnol. 2008, 24, 1433-1438. [CrossRef]

63. Eyberger, A.L.; Dondapati, R.; Porter, J.R. Endophyte fungal isolates from Podophyllum peltatum produce podophyllotoxin. J. Nat. Prod. 2006, 69, 1121-1124. [CrossRef] [PubMed]

64. Li, X.; Zhai, X.; Shu, Z.; Dong, R.; Ming, Q.; Qin, L.; Zheng, C. Phoma glomerata D14: An endophytic fungus from Salvia miltiorrhiza that produces Salvianolic acid C. Curr. Microbiol. 2016, 73, 31-37. [CrossRef] [PubMed]

65. Maehara, S.; Simanjuntak, P.; Maetani, Y.; Kitamura, C.; Ohashi, K.; Shibuya, H. Ability of endophytic filamentous fungi associated with Cinchona ledgeriana to produce Cinchona alkaloids. J. Nat. Med. 2013, 67, 421-423. [CrossRef] [PubMed]

66. Chen, X.; Sang, X.; Li, S.; Zhang, S.; Bai, L. Studies on a chlorogenic acid-producing endophytic fungi isolated from Eucommia ulmoides Oliver. J. Ind. Microbiol. Biotechnol. 2010, 37, 447-454. [CrossRef] [PubMed]

67. Ming, Q.; Han, T.; Li, W.; Zhang, Q.; Zhang, H.; Zheng, C.; Huang, F.; Rahman, K.; Qin, L. Tanshinone IIA and tanshinone i production by Trichoderma atroviride D16, an endophytic fungus in Salvia miltiorrhiza. Phytomedicine 2012, 19, 330-333. [CrossRef] [PubMed]

68. Tan, X.; Zhou, Y.; Zhou, X.; Xia, X.; Wei, Y.; He, L.; Tang, H.; Yu, L. Diversity and bioactive potential of culturable fungal endophytes of Dysosma versipellis; A rare medicinal plant endemic to China. Sci. Rep. 2018, 8, 1-9. [CrossRef]

69. Hodkinson, T.R.; Doohan, F.M.; Saunders, M.J.; Murphy, B.R. Endophytes for a Growing World; Cambridge University Press: Cambridge, UK, 2019; pp. 3-22.

70. Ancheeva, E.; Daletos, G.; Proksch, P. Bioactive secondary metabolites from endophytic fungi. Curr. Med. Chem. 2019, 26. [CrossRef]

71. Deshmukh, K.S.; Verekar, S.A.; Bhave, S.V. Endophytic fungi: A reservoir of antibacterials. Front. Microbiol. $2014,5,715$.

72. Martinez-Klimova, E.; Rodríguez-Peña, K.; Sánchez, S. Endophytes as sources of antibiotics. Biochem. Pharmacol. 2017, 134, 1-17. [CrossRef] [PubMed]

73. Deshmukh, S.K.; Gupta, M.K.; Prakash, V.; Saxena, S. Endophytic fungi: A source of potential antifungal compounds. J. Fungi 2018, 4, 77. [CrossRef]

74. Alvin, A.; Miller, K.I.; Neilan, B.A. Exploring the potential of endophytes from medicinal plants as sources of antimycobacterial compounds. Microbiol. Res. 2014, 169, 483-495. [CrossRef]

75. Chen, L.; Zhang, Q.-Y.; Jia, M.; Ming, Q.-L.; Yue, W.; Rahman, K.; Qin, L.-P.; Han, T. Endophytic fungi with antitumor activities: Their occurrence and anticancer compounds. Crit. Rev. Microbiol. 2014, 42, 1-20. [CrossRef]

76. Kharwar, R.N.; Mishra, A.; Gond, S.K.; Stierle, A.; Stierle, D. Anticancer compounds derived from fungal endophytes: Their importance and future challenges. Nat. Prod. Rep. 2011, 28, 1208-1228. [CrossRef]

77. Toghueo, K.M.; Boyom, F.F. Endophytes from ethno-pharmacological plants: Sources of novel antioxidants- A systematic review. Biocatal. Agric. Biotechnol. 2019, 22, 101430. [CrossRef]

78. Corrêa, R.C.G.; Rhoden, S.A.; Mota, T.R.; Azevedo, J.L.; Pamphile, J.A.; de Souza, C.G.M.; Polizeli, M.D.; Bracht, A.; Peralta, R.M. Endophytic fungi: Expanding the arsenal of industrial enzyme producers. J. Ind. Microbiol. Biotechnol. 2014, 41, 1467-1478. [CrossRef]

79. Khan, A.L.; Shahzad, R.; Al-Harrasi, A.; Lee, I.-J. Endophytic microbes: A resource for producing extracellular enzymes. In Endophytes: Crop Productivity and Protection; Springer: Cham, Switzerland, 2017; pp. 95-110.

80. Hoffmeister, D.; Keller, N.P. Natural products of filamentous fungi: Enzymes, genes, and their regulation. Nat. Prod. Rep. 2007, 24, 393-416. [CrossRef] [PubMed]

81. Keller, N.P.; Turner, G.; Bennett, J.W. Fungal secondary metabolism-From biochemistry to genomics. Nat. Rev. Microbiol. 2005, 3, 937-947. [CrossRef] [PubMed]

82. Khaldi, N.; Seifuddin, F.T.; Turner, G.; Haft, D.; Nierman, W.C.; Wolfe, K.H.; Fedorova, N.D. SMURF: Genomic mapping of fungal secondary metabolite clusters. Fungal Genet. Biol. 2010, 47, 736-741. [CrossRef] [PubMed]

83. Keller, N.P. Fungal secondary metabolism: Regulation, function and drug discovery. Nat. Rev. Microbiol. 2019, 17, 167-180. [CrossRef]

84. Rutledge, P.J.; Challis, G.L. Discovery of microbial natural products by activation of silent biosynthetic gene clusters. Nat. Rev. Microbiol. 2015, 13, 509-523. [CrossRef] [PubMed]

85. Fisch, K.M.; Gillaspy, A.F.; Gipson, M.; Henrikson, J.C.; Hoover, A.R.; Jackson, L.; Najar, F.Z.; Wägele, H.; Cichewicz, R.H. Chemical induction of silent biosynthetic pathway transcription in Aspergillus niger. J. Ind. Microbiol. Biotechnol. 2009, 36, 1199-1213. [CrossRef] 
86. Schüller, A.; Wolansky, L.; Berger, H.; Studt, L.; Gacek-Matthews, A.; Sulyok, M.; Strauss, J. A novel fungal gene regulation system based on inducible VPR-dCas9 and nucleosome map-guided sgRNA positioning. Appl. Microbiol. Biotechnol. 2020, 104, 9801-9822. [CrossRef] [PubMed]

87. Bode, H.B.; Bethe, B.; Höfs, R.; Zeeck, A. Big effects from small changes: Possible ways to explore nature's chemical diversity. ChemBioChem 2002, 3, 619-627. [CrossRef]

88. Reen, F.J.; Romano, S.; Dobson, A.D.W.; O'Gara, F. The sound of silence: Activating silent biosynthetic gene clusters in marine microorganisms. Mar. Drugs 2015, 13, 4754-4783. [CrossRef]

89. Ahsan, T.; Chen, J.; Wu, Y.; Irfan, M.; Shafi, J. Screening, identification, optimization of fermentation conditions, and extraction of secondary metabolites for the biocontrol of Rhizoctonia solani AG-3. Biotechnol. Biotechnol. Equip. 2017, 31, 91-98. [CrossRef]

90. Ding, G.; Zheng, Z.; Liu, S.; Zhang, H.; Guo, L.; Che, Y. Photinides A-F, cytotoxic benzofuranone-derived $\gamma$-lactones from the plant endophytic fungus Pestalotiopsis photiniae. J. Nat. Prod. 2009, 72, 942-945. [CrossRef]

91. Ding, G.; Qi, Y.; Liu, S.; Guo, L.; Chen, X. Photipyrones A and B, new pyrone derivatives from the plant endophytic fungus Pestalotiopsis photiniae. J. Antibiot. 2012, 65, 271-273. [CrossRef] [PubMed]

92. Ariantari, N.P.; Daletos, G.; Mándi, A.; Kurtán, T.; Müller, W.E.G.; Lin, W.; Ancheeva, E.; Proksch, P. Expanding the chemical diversity of an endophytic fungus: Bulgaria inquinans, an ascomycete associated with mistletoe, through an OSMAC approach. RSC Adv. 2019, 9, 25119-25132. [CrossRef]

93. Hewage, R.T.; Aree, T.; Mahidol, C.; Ruchirawat, S.; Kittakoop, P. One strain-many compounds (OSMAC) method for production of polyketides, azaphilones, and an isochromanone using the endophytic fungus Dothideomycete sp. Phytochemistry 2014, 108, 87-94. [CrossRef] [PubMed]

94. Supratman, U.; Suzuki, T.; Nakamura, T.; Yokoyama, Y.; Harneti, D.; Maharani, R.; Salam, S.; Abdullah, F.F.; Koseki, T.; Shiono, Y. New metabolites produced by endophyte Clonostachys rosea B5-2. Nat. Prod. Res. 2019, 35, 1525-1531. [CrossRef]

95. Paranagama, P.A.; Wijeratne, E.M.K.; Gunatilaka, A.A.L. Uncovering biosynthetic potential of plant-associated fungi: Effect of culture conditions on metabolite production by Paraphaeosphaeria quadriseptata and Chaetomium chiversii. J. Nat. Prod. 2007, 70, 1939-1945. [CrossRef]

96. Daletos, G.; Ebrahim, W.; Ancheeva, E.; El-neketi, M. Microbial coculture and OSMAC approach as strategies to induce cryptic fungal biogenetic gene clusters. Chem. Biol. Nat. Prod. 2017, 233-284. [CrossRef]

97. Bayram, Ö.; Krappmann, S.; Ni, M.; Jin, W.B.; Helmstaedt, K.; Valerius, O.; Braus-Stromeyer, S.; Kwon, N.J.; Keller, N.P.; Yu, J.H.; et al. VelB/VeA/LaeA complex coordinates light signal with fungal development and secondary metabolism. Science 2008, 320, 1504-1506. [CrossRef]

98. Pruß, S.; Fetzner, R.; Seither, K.; Herr, A.; Pfeiffer, E.; Metzler, M.; Lawrence, C.B.; Fischer, R. Role of the Alternaria alternata blue-light receptor LreA (White-Collar 1) in spore formation and secondary metabolism. Appl. Environ. Microbiol. 2014, 80, 2582-2591. [CrossRef] [PubMed]

99. Hautbergue, T.; Jamin, E.L.; Debrauwer, L.; Puel, O.; Oswald, I.P. From genomics to metabolomics, moving toward an integrated strategy for the discovery of fungal secondary metabolites. Nat. Prod. Rep. 2018, 35, 147-173. [CrossRef]

100. Pan, R.; Bai, X.; Chen, J.; Zhang, H.; Wang, H. Exploring structural diversity of microbe secondary metabolites using OSMAC strategy: A literature review. Front. Microbiol. 2019, 10, 1-20. [CrossRef] [PubMed]

101. Stroe, M.; Netzker, T.; Scherlach, K.; Krüger, T.; Hertweck, C.; Valiante, V.; Brakhage, A.A. Targeted induction of a silent fungal gene cluster encoding the bacteria-specific germination inhibitor fumigermin. Elife 2020, 9, e52541. [CrossRef] [PubMed]

102. Bertrand, S.; Bohni, N.; Schnee, S.; Schumpp, O.; Gindro, K.; Wolfender, J.L. Metabolite induction via microorganism co-culture: A potential way to enhance chemical diversity for drug discovery. Biotechnol. Adv. 2014, 32, 1180-1204. [CrossRef]

103. Khare, E.; Mishra, J.; Arora, N.K. Multifaceted interactions between endophytes and plant: Developments and prospects. Front. Microbiol. 2018, 9, 15. [CrossRef]

104. Kuo, T.H.; Yang, C.T.; Chang, H.Y.; Hsueh, Y.P.; Hsu, C.C. Nematode-trapping fungi produce diverse metabolites during predator-prey interaction. Metabolites 2020, 10, 117. [CrossRef]

105. Marmann, A.; Aly, A.H.; Lin, W.; Wang, B.; Proksch, P. Co-cultivation-A powerful emerging tool for enhancing the chemical diversity of microorganisms. Mar. Drugs 2014, 12, 1043-1065. [CrossRef]

106. Moody, S.C. Microbial co-culture: Harnessing intermicrobial signaling for the production of novel antimicrobials. Future Microbiol. 2014, 9, 575-578. [CrossRef]

107. Ola, A.R.B.; Thomy, D.; Lai, D.; Brötz-Oesterhelt, H.; Proksch, P. Inducing secondary metabolite production by the endophytic fungus Fusarium tricinctum through coculture with Bacillus subtilis. J. Nat. Prod. 2013, 76, 2094-2099. [CrossRef] [PubMed]

108. Akone, S.H.; Mándi, A.; Kurtán, T.; Hartmann, R.; Lin, W.; Daletos, G.; Proksch, P. Inducing secondary metabolite production by the endophytic fungus Chaetomium sp. through fungal-bacterial co-culture and epigenetic modification. Tetrahedron 2016, 72, 6340-6347. [CrossRef]

109. Ebrahim, W.; El-Neketi, M.; Lewald, L.I.; Orfali, R.S.; Lin, W.; Rehberg, N.; Kalscheuer, R.; Daletos, G.; Proksch, P. Metabolites from the fungal endophyte Aspergillus austroafricanus in axenic culture and in fungal-bacterial mixed cultures. J. Nat. Prod. 2016, 79, 914-922. [CrossRef] [PubMed]

110. König, C.C.; Scherlach, K.; Schroeckh, V.; Horn, F.; Nietzsche, S.; Brakhage, A.A.; Hertweck, C. Bacterium induces cryptic meroterpenoid pathway in the pathogenic fungus Aspergillus fumigatus. ChemBioChem 2013, 14, 938-942. [CrossRef] 
111. Soliman, S.S.M.; Raizada, M.N. Interactions between co-habitating fungi elicit synthesis of Taxol from an endophytic fungus in host Taxus plants. Front. Microbiol. 2013, 4, 1-14. [CrossRef] [PubMed]

112. Li, C.; Sarotti, A.M.; Yang, B.; Turkson, J.; Cao, S. A New N-methoxypyridone from the co-cultivation of hawaiian endophytic fungi Camporesia sambuci FT1061 and Epicoccum sorghinum FT1062. Molecules 2017, 22, 1166. [CrossRef]

113. Wang, J.P.; Lin, W.; Wray, V.; Lai, D.; Proksch, P. Induced production of depsipeptides by co-culturing Fusarium tricinctum and fusarium begoniae. Tetrahedron Lett. 2013, 54, 2492-2496. [CrossRef]

114. Li, H.-T.; Zhou, H.; Duan, R.-T.; Li, H.-Y.; Tang, L.-H.; Yang, X.-Q.; Yang, Y.-B.; Ding, Z.-T. Inducing secondary metabolite production by co-culture of the endophytic fungus Phoma sp. and the symbiotic fungus Armillaria sp. J. Nat. Prod 2019, 82, 1009-1013. [CrossRef]

115. Zhu, F.; Lin, Y. Marinamide, a novel alkaloid and its methyl ester produced by the application of mixed fermentation technique to two mangrove endophytic fungi from the South China Sea. Chin. Sci. Bull. 2006, 51, 1426-1430. [CrossRef]

116. Zhu, F.; Chen, G.Y.; Wu, J.S.; Pan, J.H. Structure revision and cytotoxic activity of marinamide and its methyl ester, novel alkaloids produced by co-cultures of two marine-derived mangrove endophytic fungi. Nat. Prod. Res. 2013, 27, 1960-1964. [CrossRef]

117. Rojas-Aedo, J.F.; Gil-Durán, C.; Goity, A.; Vaca, I.; Levicán, G.; Larrondo, L.F.; Chávez, R. The developmental regulator Pcz1 affects the production of secondary metabolites in the filamentous fungus Penicillium roqueforti. Microbiol. Res. 2018, 212-213, 67-74. [CrossRef]

118. Brakhage, A.A. Regulation of fungal secondary metabolism. Nat. Rev. Microbiol. 2013, 11, 21-32. [CrossRef] [PubMed]

119. García-Estrada, C.; Domínguez-Santos, R.; Kosalková, K.; Martín, J.-F. Transcription factors controlling primary and secondary metabolism in filamentous fungi: The $\beta$-Lactam paradigm. Fermentation 2018, 4, 47. [CrossRef]

120. Cichewicz, R.H. Epigenome manipulation as a pathway to new natural product scaffolds and their congeners. Nat. Prod. Rep. 2010, 27, 11-22. [CrossRef] [PubMed]

121. Yang, X.L.; Huang, L.; Ruan, X.L. Epigenetic modifiers alter the secondary metabolite composition of a plant endophytic fungus, Pestalotiopsis crassiuscula obtained from the leaves of Fragaria chiloensis. J. Asian Nat. Prod. Res. 2014, 16, 412-417. [CrossRef] [PubMed]

122. Magotra, A.; Kumar, M.; Kushwaha, M.; Awasthi, P.; Raina, C.; Gupta, A.P.; Shah, B.A.; Gandhi, S.G.; Chaubey, A. Epigenetic modifier induced enhancement of fumiquinazoline C production in Aspergillus fumigatus (GA-L7): An endophytic fungus from Grewia asiatica L. AMB Express 2017, 7, 1-10. [CrossRef]

123. González-Menéndez, V.; Pérez-Bonilla, M.; Pérez-Victoria, I.; Martín, J.; Muñoz, F.; Reyes, F.; Tormo, J.R.; Genilloud, O. Multicomponent analysis of the differential induction of secondary metabolite profiles in fungal endophytes. Molecules 2016, 21, 234. [CrossRef]

124. Beau, J.; Mahid, N.; Burda, W.N.; Harrington, L.; Shaw, L.N.; Mutka, T.; Kyle, D.E.; Barisic, B.; Van Olphen, A.; Baker, B.J. Epigenetic tailoring for the production of anti-infective cytosporones from the marine fungus Leucostoma persoonii. Mar. Drugs 2012, 10, 762-774. [CrossRef] [PubMed]

125. Li, G.; Kusari, S.; Golz, C.; Laatsch, H.; Strohmann, C.; Spiteller, M. Epigenetic modulation of endophytic Eupenicillium sp. LG41 by a histone deacetylase inhibitor for production of decalin-containing compounds. J. Nat. Prod. 2017, 80, 983-988. [CrossRef] [PubMed]

126. Sun, J.; Awakawa, T.; Noguchi, H.; Abe, I. Induced production of mycotoxins in an endophytic fungus from the medicinal plant Datura stramonium L. Bioorgan. Med. Chem. Lett. 2012, 22, 6397-6400. [CrossRef]

127. González-Menéndez, V.; Crespo, G.; Toro, C.; Martín, J.; De Pedro, N.; Tormo, J.R.; Genilloud, O. Extending the metabolite diversity of the endophyte Dimorphosporicola tragani. Metabolites 2019, 9, 197. [CrossRef] [PubMed]

128. Brakhage, A.A.; Schuemann, J.; Bergmann, S.; Scherlach, K.; Schroeckh, V.; Hertweck, C. Activation of fungal silent gene clusters: A new avenue to drug discovery. In Natural Compounds as Drugs; Birkhäuser: Basel, Switzlerland, 2008; pp. 1-12.

129. Wiemann, P.; Keller, N.P. Strategies for mining fungal natural products. J. Ind. Microbiol. Biotechnol. 2014, 41, 301-313. [CrossRef]

130. Knox, P.B.; Keller, P.N. Key players in the regulation of fungal secondary metabolism. In Biosynthesis and Molecular Genetics of Fungal Secondary; Zeilinger, S., Martín, J.F., García-Estrada, C., Eds.; Springer: New York, NY, USA, 2015; pp. 13-28.

131. Macheleidt, J.; Mattern, D.J.; Fischer, J.; Netzker, T.; Weber, J.; Schroeckh, V.; Valiante, V.; Brakhage, A.A. Regulation and role of fungal secondary metabolites. Annu. Rev. Genet. 2016, 50, 371-392. [CrossRef]

132. Zeilinger, S.; Martín, J.F.; García-Estrada, C. Fungal secondary metabolites in the "OMICS" era. In Biosynthesis and Molecular Genetics of Fungal Secondary; Zeilinger, S., Martín, J.F., García-Estrada, C., Eds.; Springer: New York, NY, USA, 2015; pp. 1-12.

133. Bergmann, S.; Schümann, J.; Scherlach, K.; Lange, C.; Brakhage, A.A.; Hertweck, C. Genomics-driven discovery of PKS-NRPS hybrid metabolites from Aspergillus nidulans. Nat. Chem. Biol. 2007, 3, 213-217. [CrossRef]

134. Zabala, A.O.; Xu, W.; Chooi, Y.H.; Tang, Y. Characterization of a silent azaphilone gene cluster from Aspergillus niger ATCC 1015 reveals a hydroxylation-mediated pyran-ring formation. Chem. Biol. 2012, 19, 1049-1059. [CrossRef] [PubMed]

135. Derntl, C.; Kluger, B.; Bueschl, C.; Schuhmacher, R.; Mach, R.L.; Mach-Aigner, A.R. Transcription factor Xpp1 is a switch between primary and secondary fungal metabolism. Proc. Natl. Acad. Sci. USA 2017, 114, E560-E569. [CrossRef] [PubMed]

136. Wu, G.; Zhou, H.; Zhang, P.; Wang, X.; Li, W.; Zhang, W.; Liu, X.; Liu, H.W.; Keller, N.P.; An, Z.; et al. Polyketide production of Pestaloficiols and Macrodiolide Ficiolides revealed by manipulations of epigenetic regulators in an endophytic fungus. Org. Lett. 2016, 18, 1832-1835. [CrossRef] [PubMed]

137. Skellam, E. Strategies for engineering natural product biosynthesis in fungi. Trends Biotechnol. 2019, 37, 416-427. [CrossRef] 
138. Chiang, Y.M.; Oakley, C.E.; Ahuja, M.; Entwistle, R.; Schultz, A.; Chang, S.L.; Sung, C.T.; Wang, C.C.C.; Oakley, B.R. An efficient system for heterologous expression of secondary metabolite genes in Aspergillus nidulans. J. Am. Chem. Soc. 2013, 135, 7720-7731. [CrossRef] [PubMed]

139. Oakley, C.E.; Ahuja, M.; Sun, W.W.; Entwistle, R.; Akashi, T.; Yaegashi, J.; Guo, C.J.; Cerqueira, G.C.; Russo Wortman, J.; Wang, C.C.C.; et al. Discovery of McrA, a master regulator of Aspergillus secondary metabolism. Mol. Microbiol. 2017, 103, 347-365. [CrossRef]

140. Bok, J.W.; Keller, N.P. LaeA, a regulator of secondary metabolism in Aspergillus spp. Eukaryot. Cell 2004, 3, 527-535. [CrossRef] [PubMed] 